\title{
THE ROLE OF PRIVATE VERSUS GOVERNMENTAL VENTURE CAPITAL IN FOSTERING JOB CREATION DURING THE CRISIS
}

\author{
Annalisa Croce \\ Politecnico di Milano \\ Dipartimento di Ingegneria Gestionale \\ via Lambruschini 4/b, 20156, (Milano - Italy) \\ Orcid ID: 0000-0003-1026-2218 \\ Jose Martí* \\ Universidad Complutense de Madrid \\ Department of Accounting and Finance \\ Facultad de CC. EE. y EE.; Edificio 6 - Despacho 51 \\ E -28223 Pozuelo de Alarcón (Madrid - Spain) \\ Orcid ID: 0000-0003-0251-8287 \\ Carmelo Reverte \\ Technical University of Cartagena (Spain) \\ Department of Accounting and Finance \\ c/Real, 3; E-30201 Cartagena (Murcia - Spain) \\ Orcid ID: 0000-0002-5947-664X
}

\begin{abstract}
We analyze whether young entrepreneurial ventures backed by different types of venture capital firms, i.e., private (PVCs) vs. government-owned (GOVCs), experience higher employment growth than a matched control group of non-venture-backed companies and whether this effect is particularly relevant in a period of crisis. We base our analyses on a sample of 384 Spanish early-stage VC-backed companies financed during the period 2005-2013 (173 GOVC-backed and 211 PVC-backed) and a control group of 888 non-venture-backed peers. Our results show that PVCs exert a higher impact on employment growth in invested companies than GOVCs in investments carried out during a period of crisis whereas the opposite is found in the case of investments completed before the crisis. Moreover, we find that PVCs enhance their job-creation performance during a period of crisis while GOVCs significantly reduce their impact on employment in the investments carried out during the crisis. These findings could be attributed to the higher value added and monitoring granted by PVCs during the crisis.
\end{abstract}

Keywords: venture capital, employment growth, government, crisis, impact

JEL classification: G24, M13, C23

\footnotetext{
*Corresponding author:

Email: jmartipe@ccee.ucm.es

Phone: (34) 913942310
}

This is a post-peer-review, pre-copyedit version of an article published in SMALL BUSINESS ECONOMICS, 2019, 53:4, 879-900. The final authenticated version is available online at: http://dx.doi.org/10.1007\%2Fs11187-018-0108-3 


\section{Introduction}

One of the major side effects of the 2008 financial crisis was the significant reduction in the availability of finance for entrepreneurial ventures (Cowling et al., 2012; Mason and Harrison, 2015), which resulted in significant reductions in output, investment and employment across the world (European Commission, 2009; Ollivaud and Turner, 2015; Young, 2014). In sharp contrast with a pre-crisis period characterized by loose credit conditions (Davis, 2011), where banks were aggressively lending to gain market share, they remarkably tightened their lending criteria and became more risk-averse during the crisis (Mills and McCarthy, 2014). This situation was even more accentuated by the new financial regulations (Basel Committee on Banking Supervision, 2013) that required banks to hold more capital in the case of risky investments.

Young innovative entrepreneurial ventures play a critical role in modern knowledgebased economies because they are an important source of new jobs, productivity growth and radical innovations (Criscuolo et al., 2014). These entrepreneurial ventures are especially affected by financial constraints under normal economic conditions. The lack of collateral and the presence of asymmetric information and agency problems are the main reasons for their difficulties in raising external capital (Beck et al., 2008; Binks et al., 1992; Carpenter and Petersen, 2002). After the burst of the financial crisis, these concerns were even aggravated. Since employment generation is indeed considered as an important policy objective (Minola et al., 2017), providing long-term finance to young innovative entrepreneurial ventures should then become a priority for governments.

One of the instruments traditionally used to reduce the financing gap faced by young innovative entrepreneurial ventures is venture capital (VC, hereafter). An extensive theoretical literature (e.g., Admati and Pfleiderer, 1994; Bergemann and Hege, 1998; Cornelli and Yosha, 2003; Hall and Lerner, 2010; Hellman, 1998) suggests that the combination of intensive 
screening, monitoring and powerful control rights provided by venture capitalists (hereafter, VCs) should alleviate agency problems between entrepreneurs and institutional investors.

But VC markets did not evolve in Continental Europe as they did in the US due to the lack of some basic conditions in the economic environment (Martí and Balboa, 2006). As a consequence, governments from various countries and even the European Commission created schemes to foster VC financing through the establishment of governmental VC firms (hereafter, GVCs) (Colombo et al. 2016; Cumming et al. 2009). GVCs aim to pursue investments that yield social payoffs and positive externalities for society as a whole, such as regional development and job creation. In the debate about the likelihood that GVCs may crowd out rather than complement private VC firms (PVCs, hereafter) (Leleux and Surlemont, 2003), a further differentiation between government-owned (hereafter, GOVCs) and governmentsupported VCs has emerged in the literature. GOVCs are firms entirely backed by government entities whereas government-supported VCs are privately-operated VC firms that receive significant financing from governmental entities (Brander et al., 2015).

There are a plethora of studies indicating that companies backed by VCs have contributed significantly to job creation (e.g., Alemany and Martí 2005; Davila et al. 2003; Engel and Keilbach 2007; Paglia and Harjoto 2014; Puri and Zarutskie 2012). The existing evidence of the impact of GVCs' investments on firm performance shows, however, negligible (Balboa et al., 2007; Bertoni and Tykvová, 2015; Grilli and Murtinu, 2014) or negative (Alperovych et al., 2015) results. Nevertheless, in all of these studies, there is no explicit connection to the surrounding economic context in which VC firms developed their activities (van den Pol, 2016). As Paglia and Harjoto (2014) highlight, the literature on the impact of VC financing on growth and job creation for entrepreneurial ventures is still underdeveloped.

In this regard, the 2008 financial crisis provides us with an empirical setting to explore the influence of crisis-induced supply shocks on VC portfolio dynamics (Conti et al., 2016). In 
this work, we aim to analyze the impact of the investments of GOVCs and PVCs on employment growth in their portfolio companies (compared to the effect induced on a matched control group of non VC-backed entrepreneurial ventures), both before and during a period of crisis.

We focus on early-stage VC investments recorded in Spain between 2005 and 2013, following their evolution throughout the crisis until 2016. We test our hypotheses on the Spanish VC market for three reasons. First, excluding Greece, Spain was the EU country that experienced the highest negative impact of the 2008 crisis on employment. From more than 1.8 million people unemployed in 2008 (8.3\% of the active workforce), this number grew to 6.05 million people by mid-2013, representing $26.1 \%$ of the active workforce (Instituto Nacional de Estadística, 2016). Second, the amount of VC investments received in 2008 by Spanish companies was only behind the amounts recorded by British, German and French firms (Invest Europe, 2016). Third, GOVCs played a key role in the early development of the Spanish VC market (Balboa et al., 2007).

We base our analysis on a sample of 384 young entrepreneurial ventures, which received the first round of VC financing during the period 2005-2013, 173 of which from GOVCs and the remaining 211 from PVCs, and a control group of 888 non VC-backed entrepreneurial ventures. Our results reveal that PVCs have a higher impact on employment growth than GOVCs in the case of investments carried out during a period of crisis.

The structure of the paper is as follows. In section 2, we present the theoretical background and develop our hypotheses. In section 3, we present the data and the methodology used to test our hypotheses. We show our results in section 4. Finally, in section 5, we discuss our findings and conclude. 


\section{Theory and hypotheses development}

2.1. Information asymmetries, venture capital and firm growth before and during the crisis

The existence of frictions such as information asymmetry, agency costs and transaction costs (Fama and Jensen, 1983; Jensen and Meckling, 1976; Myers and Majluf, 1984) affects a firm's capacity to access external sources of funds. Entrepreneurial ventures are most affected by information asymmetry problems (adverse selection and moral hazard) when accessing external sources of funds to finance their investment projects (Berger and Udell, 1998; Brav, 2009). As a result, the scarcity of external finance hinders a firm’s ability to grow (Gompers, 1995; Michaelas et al., 1999).

In the case of entrepreneurial ventures, the lack of public information on standardized financial statements and their growth potential, in particular in young innovative high-growth oriented firms, originates information asymmetries faced by potential financiers that result in a constrained access to external finance (Beck et al., 2008; Lerner, 2002). It is thus difficult for lenders to distinguish potentially successful businesses from less successful ones (adverse selection) and, as a result, lenders may provide less funding than the company actually needs and also require a higher interest rate to compensate for the higher perceived risk (Wilson, 2015).

On the other hand, it is hard for lenders to be sure that once the funds are granted borrowers do not take excessive risks or misuse the funds (moral hazard). One way for lenders to overcome the problems associated with information asymmetries is to require collateral. However, the intangible nature of the assets of young innovative firms limits their possibility to provide collateral. Hence, these firms are likely to be credit constrained, regardless of the quality and growth potential of their investment projects (Wilson, 2015).

All of these problems were aggravated by the significant reduction in the availability of finance for entrepreneurial ventures during the financial crisis (Cowling et al., 2012; Mason 
and Harrison, 2015), which resulted in a significant drop in the supply of bank finance (Davis, 2011), and the increased risk aversion of banks (Mills and McCarthy, 2014). This point makes our analysis of entrepreneurial ventures' growth around the financial crisis particularly noteworthy.

VC firms are better able to address informational asymmetries than other financial intermediaries because of their screening (Amit et al., 1998; Tyebjee and Bruno, 1984), monitoring (Kaplan and Strömberg, 2003; Lerner, 1995; Sahlman, 1990) and value-adding (Arthurs and Busenitz, 2006; Hsu, 2006; Sapienza et al., 1996; Sørensen, 2007) abilities. In addition, VC endorsement provides a sort of certification about the quality of the portfolio firm to uninformed third parties (Megginson and Weiss, 1991). The combination of intensive screening, monitoring and powerful control rights provided by VC should alleviate agency problems between entrepreneurs and institutional investors, thereby leading to improved governance and operations in portfolio firms. In this regard, there is evidence on the role VC firms play in alleviating financial constraints in investee firms (Balboa et al., 2017; Bertoni et al., 2013, 2010; Engel and Stiebale, 2014). Furthermore, the extant literature also provides evidence on the impact of VC finance on R\&D productivity (Kortum and Lerner, 2000), product time-to-market (Hellmann and Puri, 2000), sales growth (Engel and Keilbach, 2007), and productivity (Chemmanur et al., 2011; Croce et al., 2013; Croce and Martí, 2016)

In addition to the value-adding services and support provided, the funding allocated by VC firms and the reduction in the dependency of investments on internal cash flows lead to an increase in investment activity (Bertoni et al., 2013, 2010), which explains the empirical evidence on the impact of VC finance on employment growth supported in the literature (e.g., Alemany and Martí, 2005; Bertoni et al., 2011; Davila et al., 2003; Grilli and Murtinu, 2014; Paglia and Harjoto, 2014; Puri and Zarutskie, 2012). Accordingly, we expect that VC-backed entrepreneurial ventures will show higher employment growth than similar non VC-backed 
entrepreneurial ventures, especially in a period of crisis, as untreated entrepreneurial ventures become even more credit-constrained due to the lack of liquidity in the financial system.

\subsection{The differential effect of PVCs versus GOVCs on employment growth}

The extension of the VC industry to other countries different from the US was subject to various institutional forces that impacted its behavior (Bruton et al., 2005). In the case of the VC market in Continental Europe, the lack of an adequate environment (Martí and Balboa, 2006) led to the creation of many GOVCs in different countries to complement the limited early-stage investment activity carried out by PVCs (Colombo et al. 2016; Cumming et al. 2009). Consequently, any attempt to analyze the effect of VC on portfolio companies in this geography should address the question on whether GOVCs are able to exert the same positive effect on performance found in the case of PVCs.

There is still limited evidence on the separate impact of GOVCs and PVCs on their investee companies’ performance. Bertoni and Tykvová (2015) find that GOVCs have no impact on invention and innovation whereas PVCs do have a positive effect. Alperovych et al. (2015) report a reduction in efficiency in companies backed by GOVCs when compared to that of their non VC-backed peers. Regarding employment growth, Balboa et al. (2007) find a negligible effect of GOVCs' investments on employment growth in the nineties. Grilli and Murtinu (2014) find that independent VCs exert a positive effect on sales but not on employment growth ${ }^{1}$ whereas GOVCs show a negligible effect on both sales and employment growth. However, they do not specifically test whether the differential growth exerted by independent VCs versus that of GOVCs on their investee companies is significant. In addition, both studies do not consider the role of the financial crisis.

\footnotetext{
${ }^{1}$ Except in the case of OLS estimation.
} 
GOVCs are usually created to invest in depressed areas or in strategic sectors. These VC firms are frequently managed by civil servants directly appointed by government officials. Only in a limited number of cases, professional managers are hired in the market. As a result, GOVCs show some characteristics that may hinder their value-creation abilities. First, GOVCs' managers may lack the incentives or relevant experience in the VC industry to properly screen, monitor and add value to new ventures. The salaries of the managers of GOVCs, often civil servants, rarely apply performance-based compensation structures similar to those of PVCs (Manigart et al., 2002), and their previous experience is usually linked to firms belonging to sectors with predictable cash flows, which are not frequently related to high-growth industries (Alperovych et al., 2015). Hence, these managers are less likely to screen the best possible targets, ${ }^{2}$ to put pressure on monitoring their portfolio firms and to maximize value at the time of divesting (Muzyka et al., 1996). Second, GOVCs are less likely to have a rich network of business contacts (e.g., suppliers, customers, institutional investors), and this is a key characteristic in the process whereby VCs add value to their portfolio firms (Hochberg et al., 2007). Third, the evidence on the lower involvement in value-adding activities of managers of captive funds, when compared to those of independent VC funds (Knockaert and Vanacker, 2013), is also applicable to GOVCs because their only source of funding comes from the government.

In addition, GOVCs usually manage excessive funds relative to the number of VC managers they have (Cumming et al. 2017; Cumming and MacIntosh 2007). This situation leads to a large number of investee firms per investment manager, which is a critical reference of a VC firm's value-adding capabilities (Balboa et al., 2011). Portfolio firm performance is conditioned by the attention devoted by VCs (Balboa et al., 2011; Jääskeläinen et al., 2006).

\footnotetext{
${ }^{2}$ Nevertheless, Guerini and Quas (2015) find that GVCs' managers possess good screening abilities and certify their investee firms by increasing the likelihood of obtaining a subsequent financing round carried out by PVCs.
} 
Since there is a trade-off between VCs' attention to portfolio firms and the size of the portfolio (Kanniainen and Keuschnigg, 2004), we argue that one reason for the lower performance found in companies backed by GOVCs is the larger size of their portfolios compared to the number of dedicated investment managers. Entrepreneurial ventures at an early stage require a higher monitoring activity and more support from VCs (Gorman and Sahlman, 1989). Nevertheless, GOVCs are less engaged in value-adding and coaching for their portfolio firms than PVCs (Colombo et al., 2016; Luukkonen et al., 2013).

VC value creation is not, however, only based on non-financial value-adding services. We argue that GOVCs usually concentrate their investments in regions or sectors that are most affected by information asymmetries. Therefore, the funding provided should exert a positive effect on their investment activity (Bertoni et al., 2013, 2010). In contrast, other similar non VC-backed small companies located in the same regions or belonging to the same activity sectors will be more financially constrained (Berger and Udell, 1998; Brav, 2009). In addition, GOVCs focus on low-growth industries (Alperovych et al., 2015), which are mostly laborintensive. As a result, even in the absence of proper screening and limited non-financial value added, GOVCs may fuel at least employment growth, albeit not other performance measures, in their portfolio firms. For this reason, VC is used as a tool of government intervention to foster job creation (Cumming and MacIntosh, 2006; Minola et al., 2017), and there is empirical evidence of the positive impact of governmental VC on employment in different countries (Colombo et al., 2016; Lerner, 1999).

Therefore, both PVCs and GOVCs may fuel employment growth in their investee firms in a period of normal economic activity. Hence, our first hypothesis is as follows:

H1: Entrepreneurial ventures backed by GOVCs do not show a significantly different employment growth than those backed by PVCs in a period of normal economic activity. 


\subsection{The effect of the crisis on the investment activity carried out by PVCs and GOVCs}

Since most PVCs manage closed-end funds that can only be invested while the investment period (usually from 3 to 5 years) is open, the investment activity must continue even during a period of crisis. If they do not invest the funds they have under management they could be sending a negative signal to the limited partners (Balboa and Martí, 2007). But, certainly, PVCs will place extra efforts in enhancing performance in an adverse scenario because their future compensation (i.e., carried interest) is conditioned by future returns. Hence, since similar non VC-backed entrepreneurial ventures do not have access to external finance or value-adding services at a time of increased financial constraints, we argue that the differential growth between companies backed by PVCs and untreated entrepreneurial ventures should be significantly higher in the case of investments carried out during a period of crisis. In other words, we expect that the impact of PVCs on employment growth is higher for entrepreneurial ventures financed during the crisis than that engendered in those financed before the crisis. Our Hypothesis 2 is as follows:

H2: Entrepreneurial ventures backed by PVCs during a period of crisis show higher employment growth than those backed by PVCs in a period of normal economic activity.

Conversely, in the case of GOVCs, managers' compensation is not related to portfolio returns. In addition, government agencies backing those GOVCs might be pressed to invest selfishly to overcome the short-term effects of the crisis on employment, especially in the case of GOVCs located in underdeveloped regions (Alperovych et al., 2015). Furthermore, their managers might be even pressed by government authorities to invest in troubled companies, which are not acceptable targets for VCs, to avoid firm closures.

Therefore, the lack of return-based incentives and the pressure of government officials may hinder even further the screening and monitoring abilities of GOVCs. Hence, our third and fourth hypotheses are as follows: 
H3: Entrepreneurial ventures backed by GOVCs during a period of crisis show lower employment growth than those backed by GOVCs in a period of normal economic activity.

H4: Entrepreneurial ventures backed by GOVCs show lower employment growth than those backed by PVCs in the case of investments carried out during a period of crisis.

\section{Methodology and data}

\subsection{Research setting: Overview of the Spanish VC market}

The Spanish VC market is a suitable test-bed for our analysis. The initial development of the market was basically sponsored by government authorities. The first VC firm operating in Spain was a GOVCs (SODIGA) established in 1972. In 1986, out of the 22 existing VCs, 18 were GOVCs, most of them created with a regional focus (Balboa and Martí, 2004). It was not until the early nineties when the number of PVCs became larger than the number of GOVCs (Balboa et al., 2007). By 2017, however, the number of GOVCs decreased to 19, from a maximum of 21 GOVCs in the nineties, out of a total of 342 active VC and private equity firms (182 of which were international firms mostly investing directly from abroad) operating in Spain (Alférez, 2018). ${ }^{3}$

In the 1990s, the investment activity of GOVCs in Spain mainly focused on filling the equity gap in underdeveloped regions. Around two thirds of their investments were concentrated in less developed regions whereas PVCs concentrated two thirds of their activity in developed regions (Balboa et al., 2007). In the new century, the concentration of the investments of GOVCs in less developed regions has decreased to around $60 \%$, mainly due to the active role of three governmental VCs located in the Basque Country and Navarre, which are developed regions. In contrast, around $90 \%$ of the investments of PVCs focus on developed

\footnotetext{
${ }^{3}$ The estimated number of private firms only focusing on VC investing is 109, out of which 51 are international firms.
} 
regions. Regarding the relative importance of the amounts invested by GOVCs, their share in the total amount of VC invested in the period 2015-2017 ranges between 5\% and 8\% (Alférez, 2018). Since the geographical (and to some extent also the sector) focus of the investments is so different, syndication between GOVCs and PVCs is virtually non-existent. Nevertheless, there is syndication among PVCs and also among different GOVCs (e.g., in Asturias there are three different GOVCs that jointly participate in several companies). Table 1 shows a higher focus of GOVCs on labor-intensive industries than PVCs and a decrease of their investment activity throughout the crisis.

In sum, GOVCs played an initial role as early developers of the VC market in Spain, but also today as equity providers in areas and sectors where PVCs rarely invest.

[Insert Table 1 around here]

\subsection{Sample construction}

Our empirical analyses are based on a sample of Spanish young entrepreneurial ventures that received a first VC investment between 2005 and 2013. We focus on this period to have a balanced number of companies that received VC finance before and after the crisis started. We consider pre-crisis investments as those carried out between 2005 and 2008, when the Spanish GDP growth was positive (see Figure 1), whereas investments performed during the crisis are those closed since 2009. We resorted to the detailed catalog of VC deals updated by Webcapitalriesgo to prepare the official annual reports of the Spanish Private Equity and Venture Capital Association (ASCRI). Webcapitalriesgo (2016) reports 1,717 early-stage VC deals closed between 2005 and 2013. Excluding syndication duplicates, the number of entrepreneurial ventures affected by those deals is 1,405 . We only focus on young entrepreneurial ventures (i.e., those funded in the first 5 years of existence) and, accordingly, we excluded companies founded before 2000 as the sample collects VC investments starting from 2005. We selected 945 VC-backed entrepreneurial ventures that meet this requirement, 
407 backed by PVCs and 538 by GVCs. Out of the 538 companies backed by GVCs, 443 companies received investments from GOVCs, while the remaining 95 were funded by government-supported VCs. In this work, we focus on GOVCs to validate the direct role played by government authorities in the VC market.

In order to test our research hypotheses, we constructed a control group of entrepreneurial ventures that did not receive VC (i.e., non VC-backed companies). To define this control group, for each VC-backed entrepreneurial venture, we downloaded from Orbis a list of 15 non VCbacked companies with the following characteristics: same activity sector and similar size (assets and sales) and age at the time of the related VC-backed initial round. Out of these companies, we deleted from this randomly-selected group those for which at least three consecutive years of accounting data were not available, creating an initial control group of 12,955 non VC-backed entrepreneurial ventures.

We downloaded from Orbis accounting and employment data related to both groups of entrepreneurial ventures (i.e., VC-backed and non VC-backed). We keep companies for which we observe at least two consecutive years of the variables of interest. Moreover, as to VCbacked, we keep companies for which we observe both pre- and post-investment data to correctly evaluate the impact of VC. The sample is then reduced to 10,746 non VC-backed companies and to 397 VC-backed companies (217 backed by PVCs and 182 backed by GOVCs).

Then, in order to control as much as possible for the selection on observables (i.e., the differences in sample composition before the entry of the VC investors), we extracted a matched sample. We resorted to a propensity-score matching (PSM) method to find, for each company that received VC in year t, a group of non VC-backed companies (i.e., three control group companies per each sample company, with replacement) that had the most similar probability 
of receiving VC. Matching is performed using nearest-neighbor PSM. ${ }^{4}$ Propensity scores were obtained by estimating, for each year of VC financing (from 2005 to 2013), a probit model in which the dependent variable is the probability of receiving VC and the independent variables include age in logarithms, size (measured by the log of the average number of employees between year $\mathrm{t}$ and $\mathrm{t}-1$ ), as well as region and industry dummies. ${ }^{5}$ We were able to find a suitable matched group of 888 non VC-backed pairs for 384 VC-backed entrepreneurial ventures (211 backed by PVCs and 173 backed by GOVCs).

The final sample composition is reported in Table 2 by foundation year, activity sector and region. The investments of both GOVCs and PVCs are more prevalent in the 'Other services ${ }^{6}$ sector, accounting for more than $30 \%$ of the total number of investments. The second sector in which they invest more is 'Pharma and R\&D' (in the case of GOVCs) and 'ICT' (for PVCs). As regards the region, Andalusia (for GOVCs) and Catalonia (for PVCs) are the regions attracting more VC investments.

[Insert Table 2 around here]

In Table 3, we report the distribution of the sample by type of region (developed versus underdeveloped regions), ${ }^{7}$ size at the time of investment (small versus large, based on the median number of employees of the entrepreneurial venture at the time of matching), and year of the initial VC investment (pre-crisis and during the crisis). Consistent with its main goal of fostering regional development, GOVCs are more concentrated in underdeveloped regions than in developed ones (54.91\% versus 45.09\%) whereas PVCs basically focus on developed regions

\footnotetext{
${ }^{4}$ For a similar procedure in the VC literature, see e.g., Brau, Brown, and Osteryoung (2004), Chemmanur et al. (2011), Croce and Martí (2016), Croce et al. (2013), Engel and Keilbach (2007), Puri and Zarutskie (2012), or Tian (2012).

${ }^{5}$ We resort to the average in t and $\mathrm{t}-1$ in order to keep companies funded in the first year of their life (about 34\% of the invested companies).

${ }^{6}$ It includes firms classified under the following two-digit NACE rev2 codes: 39, 41-43, 49-53, 55, 56, 58-60, 63, 64, 68-71, 73-82, 85-88, and 90-96.

${ }^{7}$ We classify as 'Under-developed' those regions that had a per capita gross domestic product (GDP) of less than $75 \%$ of the EU average, excluding Central and Eastern European Countries.
} 
(91.47\% of the number of investee companies). Regarding the size ${ }^{8}$ of invested entrepreneurial ventures, GOVCs seem to be equally distributed among small and large companies (46.82\% of small companies versus 53.18\% of large companies) whereas the proportion of large companies invested is higher in the case of PVCs (63.98\% of large companies versus $36.02 \%$ of small companies). Finally, the sample of GOVC-backed entrepreneurial ventures is uniformly distributed across crisis including 50.29\% of companies invested during the crisis (i.e., years 2009-2013) whereas $49.71 \%$ belong to the pre-crisis period (i.e., years 2005-2008). In the case of companies backed by PVCs, the percentages are $42.18 \%$ for investments completed in the pre-crisis period versus $57.82 \%$ for those carried out during the crisis.

\section{[Insert Table 3 around here]}

In Table 4 we report the descriptive statistics and correlations for the main variables used in our study. The companies in our sample have an average of 6.898 employees. This size variable exhibits substantial variation across the sample, as illustrated by both the standard deviation and the min-max range. The growth in employment is calculated as the difference between the average size (number of employees) in the three years following the investment year and the average size in the three years before the investment. The average growth in employees is 2.105. On average, the sample companies are 3.12 years of age (1.14 in logs), with a range of variation between 1 (0 in logs) and 11 (2.398 in logs). The amount financed corresponds to an average principal value of 216,178 Euro. There is a substantial variation in the size of VC investment, which range between 0 and 19.3 million Euro. It is interesting to note that the amount financed is positively and significantly correlated with employees ( $\rho=0.228$, p-value $<1 \%$ ). Moreover, there is a significant correlation between the amount of the

\footnotetext{
${ }^{8}$ Small and large ventures are defined in accordance to the median value of number of employees of the ventures in the sample.
} 
investment and the growth rate of companies, which means that larger investments are related to those companies that are growing faster than the average.

[Insert Table 4 around here]

In Table 5, we report some preliminary analysis on the employment (in logs) of companies included in our sample. We can evaluate the effectiveness of the PSM approach (and have initial evidence about the effect of VC) by looking at the average size of treated and matched companies at and after matching. We report the employment size of the treated and matched companies at the time of matching and in the years after matching.

At the time of matching, the average $\operatorname{Ln}$ (Employees) is 1.623 (5.07 employees) for treated companies and 1.567 (4.79 employees) for matched companies, with a difference (0.056) that is not statistically different from 0 . This lack of difference is expected after PSM: treated and matched companies are similar at the time of matching. This result also holds when we disentangle whether the investment year is in the period before the crisis or during the crisis.

After the event, our descriptive statistics show that treated companies grow significantly more than control group companies, regardless of when the investment takes place (i.e., before or during the crisis). After the event, the average Ln(Employees) for treated companies (2.270, which corresponds to 9.67 employees) is larger than that of matched companies (1.572, which corresponds to 4.82 employees), with a difference (0.697) that is positive and statistically significant (p-value $<0.1 \%$ ). Combining this with the fact that these companies had similar size at the time of matching, we have some preliminary evidence that treated companies grow faster than matched companies.

Overall, these results provide evidence that PSM is effective in identifying matched companies that are similar to the treated companies at the time of matching and provides 
preliminary evidence that the treated companies grow more quickly than similar non-treated companies after, but not before, the treatment.

[Insert Table 5 around here]

\subsection{Model specification}

The impact of VC investments on employment growth is investigated according to the following model in the spirit of Brown and Earle (2017). Formally, the model is as follows:

$$
\Delta \text { Employees }_{\mathrm{i}}=\alpha_{0}+\alpha_{1} \operatorname{lnAge}_{\mathrm{i}}+\beta_{1} \mathrm{VC}_{\mathrm{i}}+\beta_{2} \text { Amount financed }_{\mathrm{i}}+\mathrm{R}_{\mathrm{i}}+\mathrm{S}_{\mathrm{i}}+\mathrm{T}_{\mathrm{i}}+\varepsilon_{\mathrm{it}}
$$

where $\Delta$ Employees $_{\mathrm{i}}$ is the difference between the number of employees in the three years following the investment year and the average number of employees in the three years before. $\ln A g e_{i}$ is the age, in logarithm, of the company at the time of investment. $\mathrm{VC}_{\mathrm{i}}$ is a dummy variable taking value 1 for VC-backed entrepreneurial ventures, and 0 otherwise. The coefficient $\beta_{1}$ indicates how many jobs are created by the entry of VC investors. Amount financed $_{\mathrm{i}}$ is the total amount invested by VCs in the portfolio company. The funding provided by VCs to financially constrained entrepreneurial ventures should influence the employment growth engendered on treated companies (Grilli and Murtinu, 2014). $R_{i}$ and $S_{i}$ are region and industry dummies, respectively; $\mathrm{T}_{\mathrm{i}}$ are year dummies that capture time-varying macroeconomic shocks; and $\varepsilon_{\text {it }}$ are i.i.d. error terms.

In order to test our research hypotheses, we modify Equation (1) to analyze the effect of the two different types of VCs on employment growth and to include the effect of the crisis:

$\Delta$ Employees $_{\mathrm{i}}=\alpha_{0}+\alpha_{1} \ln _{\text {Age }}, \mathrm{i}, \delta_{1} \mathrm{PVC}_{\mathrm{i}} *\left(\mathrm{VC}\right.$ Year before crisis $\left.\mathrm{i}_{\mathrm{i}}\right)+\delta_{2} \mathrm{PVC}_{\mathrm{i}} *$

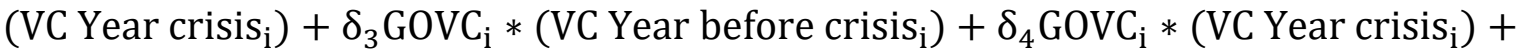
$\delta_{5}$ Syndicated $_{\mathrm{i}} *\left(\right.$ VC Year before crisis $\left._{\mathrm{i}}\right)+\delta_{6}$ Syndicated $_{\mathrm{i}} *\left(\right.$ VC Year crisis $\left._{\mathrm{i}}\right)+$ $\delta_{7}$ Amount financed $_{\mathrm{i}}+\mathrm{S}_{\mathrm{i}}+\mathrm{T}_{\mathrm{i}}+\varepsilon_{\mathrm{it}}$ 
where $P V C_{i}$ is a dummy variable taking value 1 for companies invested by PVCs. $G O V C_{i}$ is a dummy variable taking value 1 for companies invested by GOVCs. $V C$ Year crisis $_{i}$ is a dummy variable taking value 1 if a VC-backed company receives financing from 2009 to 2013, and 0 if the year of VC financing is from 2005 until 2008. VC Year before crisis $_{i}$ is defined as 1 - VC Year crisis ${ }_{\mathrm{i}}$. Similarly, for matched non VC-backed companies, the dummy is defined according to the year in which the focal company is included in the matching. We add a control for syndication by including the variable Syndicated Sthat $_{i}$ takes value 1 if the investment is carried out in syndication between GOVCs and PVCs. According to Brander et al (2005), there could be a positive effect of syndication between GVCs and PVCs, thereby suggesting an apparent complementarity between the two forms of financing. ${ }^{9}$

In order to test our hypotheses, we need to compare the coefficients $\delta_{1}, \delta_{2}, \delta_{3}$, and $\delta_{4}$, representing the impact of PVCs and GOVCs on the growth of companies invested in the years before and after the crisis started. We apply the Wald test $\delta_{1}-\delta_{3}>0$ to verify H1. We test whether the difference is not significant. Regarding H2, we compute the Wald test $\delta_{2}-\delta_{1}>$ 0 , to test whether the impact of PVCs on employment is higher in the case of investments carried out during the crisis, anticipating a positive significant difference. We apply the test $\delta_{4}-\delta_{3}>0$ to check the same for investments completed by GOVCs (H3), anticipating a negative and significant difference. Finally, to confirm our H4, we apply the Wald test $\delta_{2}-$ $\delta_{4}>0$ to check whether employment growth in companies financed during the crisis is higher in PVCs than in GOVCs, anticipating a positive and significant difference.

Because the selection process is not random, we must control for observable and nonobservable differences between the treated and non-treated companies. We control for selection on observables by resorting to the PSM methodology. However, the main shortcoming of this

\footnotetext{
${ }^{9}$ Brander et al. (2005) found that when GVCs and PVCs are present (i.e., mixed funding), total investment is higher and exit outcomes via IPO are better than with funding from PVCs or with GOVCs alone.
} 
approach is that its validity relies on the strong assumption that treated and control group companies should differ only in observable characteristics (i.e., employees, growth, region, industry and age) and that unobservable characteristics affecting the outcome do not differ systematically between the two groups. When selection is based on unobservable information this assumption is generally violated, resulting in a biased estimation of Equation (2). To overcome this potential bias, we estimate Equation (2) using a two-step least squares (2SLS) IV model. ${ }^{10}$ In the first step, we resort to the number of VC investments in the year before the receipt of VC in the specific industry in which the focal company operates. This instrument is theoretically valid because there is no reason to believe that unobserved information about a given company depends on the frequency of VC investments by industry in the previous year. Companies with higher expected future growth may operate in years with abundance or scarcity of VC investments. However, the likelihood of obtaining VC financing is higher in years in which there is abundance of VC investments. ${ }^{11}$ The instrument is also empirically strong because, in the first-step estimations, its parameter has the expected sign (positive). ${ }^{12}$

We also test whether the probability to receive VC changes around the crisis and, in order to control for this effect, we add, in the first step, a dummy variable VC Year crisis $_{i}$ taking value 1 if the receiving of VC financing is from 2009 on and 0 in the years before. Our results do not indicate a significantly different probability of receiving VC around the crisis. Other controls in the first step include the age of company (in logarithms) and its square, region and industry dummies.

\footnotetext{
${ }^{10}$ We resort to the etregress fuction in Stata 14 software.

${ }^{11}$ Finding an exclusion restriction that influences the receiving of VC and, at the same time, does not affect company performance is quite difficult. Our strategy was to exploit a mismatch between the aggregation levels of the instruments (which are aggregated by year and industry) and of the performance measure (which is instead company-specific).

${ }^{12}$ As test (not reported in the text for the sake of brevity but available upon request) we include our instrument in the second stage regressions. The aim is to verify that the average number of VC investments by industry in the year before the receipt of VC by the focal company, does not influence employment growth. The non-significance of its coefficient confirms that this instrument is a source of exogenous variation.
} 
Finally, we also analyze the impact of all investments (i.e., those carried out by PVCs and by GOVCs, before and during the crisis) throughout the crisis to provide additional evidence. In this case, we do not focus on the cross section of employment growth over a fixed period of time but on a panel including all year observations available. We estimate a series of augmented Gibrat law panel-data models (Evans, 1987) derived from the model specification used by Grilli and Murtinu (2014). This model is standard in the industrial organization literature on company growth (e.g., Sutton, 1997) and allows us to test whether the growth rates of VC-backed companies persistently increase after the investment relative to that of matched companies. The dependent variable is the logarithmic growth in the number of employees and our control variables include the logarithm of size (employees) in the previous year, Age in logarithm, a dummy VC Year crisis $_{i t}$ taking value 1 from 2009 on and 0 in the years before, in order to control for differences in employment growth during the crisis. Regional and industry fixed effects are also included. The variables of interest are the dummy variables related to the impact of VC interacted with the dummy indicating whether the receipt of financing is before or during the crisis. The dummy $\mathrm{VC}_{\mathrm{i}, \mathrm{t}}$ takes value 1 from the year of $\mathrm{VC}$ funding on and 0 otherwise.

Using OLS and fixed effects to estimate Gibrat-law models may result in biased estimates of the parameters (Arellano and Bond, 1991; Arellano and Bover, 1995; Blundell and Bond, 1998). Moreover, these methods either do not (in the case of OLS) or only partially (in the case of fixed effects) control for unobserved heterogeneity. We address these problems by using the system generalized method of moments (GMM-SYS) approach (Blundell and Bond, 1998). Specifically, we implement the GMM-SYS estimation procedure with moment conditions for endogenous variables (i.e., lagged size and VC). We also include the finite-sample correction for the two-step covariance matrix developed by Windmeijer (2005). The mean number of VC investments in the three years before is used as external instrument. The GMM methodology on panel data allows us to estimate the long-run effects of the different types of VCs on the 
employment growth of invested companies. We then apply Wald tests similar to those already reported in this section to test our hypotheses.

\section{Results}

In Panel A of Tables 6 and 7, we show the results on the cross section analysis, reporting the difference in average employment growth of investee companies three years after versus three years before the event. Table 6 refers to the results of the PSM methodology whereas Table 7 shows the estimates based on the 2SLS approach. The first column of Panel A (model 1) shows the results of our baseline model excluding controls for syndication and amount invested. In model 2, reported in the second column, we include the control for syndication. In the third column, we report the results of our baseline model, where we also control for the amount financed by VCs. The results clearly indicate that the estimated coefficients of VC variables are positive and statistically significant (at least $\mathrm{p}$-value $<1 \%$ ), regardless of the estimation method (PSM or 2SLS), the set of covariates and the period analyzed (before and during the crisis).

These results support the expectation that VC investments boost employment growth in the treated companies. The magnitude of the effect is economically significant. If we take the models with the most complete set of covariates (columns 3 of the Tables), the estimated coefficient for PVCs is between 3.240 (PSM) and 6.362 (2SLS) and for GOVCs between 7.491 (PSM) and 10.557 (2SLS) before the crisis started. Therefore, this means that, other things being equal and controlling for observable and unobservable heterogeneity, the presence of PVCs on average generated between 3.239 and 6.362 jobs and the presence of GOVCs generated between 7.491 and 10.557 jobs in investee companies in the three years following the investments carried out before the crisis started (compared to the average employment in the three years before the investment). In the case of investments closed during the crisis, always considering the models with the most complete set of covariates (columns 3 of the Tables), the estimated coefficient for PVCs is between 5.732 (PSM) and 8.814 (2SLS) and for 
GVCs is between 2.486 (PSM) and 5.530 (2SLS). In other words, other things being equal and controlling for observable and unobservable heterogeneity, the presence of PVCs investors generated between 5.732 and 8.814 jobs and the presence of GOVC investors between 2.486 and 5.530 jobs in the three years following the investments (compared to average employment in the three years before the investment) in the case of companies funded after the onset of the crisis.

[Insert Table 6 and Table 7 around here]

As to control variables, regarding syndication, our variable represents the 'additional' effect of syndication on employment growth and is not significant (with the exception of Model 2 in Table 7 in which we find a positive and 10\% significant effect in the years before crisis). This is not surprising because, when we look at our data, we find that syndication among PVCs and GOVCs was not frequent (15 cases, 3.91\% out of a total of 384 VC-backed companies). In model 3, as expected, we find that the amount financed has a positive effect on employment growth, that is, a greater amount financed favors a higher increase in employment growth of investee companies.

In order to test our hypotheses, comparing the effect of PVCs with that of GOVCs, we need to look at the results of the tests discussed in Section 3.3 and reported in Panel B of Tables 6 and 7. The tests show that employment growth in companies invested by PVCs is significantly lower than that of those backed by GVCs in the case of investments carried out in years of normal economic activity. Even though this result was not initially expected, as in our H1 we anticipated a non-significant difference, it could be caused by the different characteristics of companies funded by GOVCs (e.g., see Table 1).

In Panel C, we report the tests comparing the effect of the crisis on the impact of VC investments. Our results indicate that the impact of PVCs on employment growth is significantly higher in investments carried out during the crisis than in those completed before 
the crisis (i.e., around 2.5 workers more), while the effect is significantly reduced in GOVCs (i.e., around 5 workers less), thus confirming $\mathrm{H} 2$ and H3. As a consequence, in Panel B we find that PVCs have higher impact than GOVCs in fostering employment growth of invested companies (i.e., around 3.3 workers more), in the case of investments completed during the crisis, thus providing support to our hypothesis H4. In sum, our results indicate that GOVCs are better at fostering employment growth than PVCs in investments closed before the crisis whereas the opposite occurs in the case of investments carried out during the crisis.

Regarding the panel data approach based on the Gibrat-Law model, in Table 8 we report the estimates of GMM estimation. The PVC coefficient is significant at the $1 \%$ confidence level for investments completed during the crisis, while for GOVCs the impact is only positive and significant in investments closed before the crisis started. These results confirm that, based on the GMM estimates, the additional annual growth of PVC-backed companies is $9.19 \%$ for PVCs after the onset of the crisis and $13.22 \%$ for GOVCs in a period of normal economic activity (according to the model with the most complete set of covariates, i.e. column 3 of Table 8). Regarding the control variables, growth tends to be faster for smaller companies and slows down (at a declining rate) as the company matures.

As to the tests reported in Panels B and C, our results confirm that the employment growth in companies invested by PVCs is significantly lower than that of those backed by GOVCs in the case of investments carried out in years of normal economic activity. Conversely, for investments closed during the crisis, our results indicate the opposite: PVCs have a higher impact than GOVCs in fostering employment growth of invested companies after the onset of the economic crisis, confirming the evidence reported in Tables 6 and 7.

Concerning the impact of the crisis on VC investments, our results confirm that the impact of PVCs on employment growth is significantly higher in investments carried out during the 
crisis (not significant in model 3) than in those completed before the crisis, while the effect is significantly reduced for GOVCs, again providing further support to H2 and H3.

We completed several robustness checks. First, we estimate the effect of VC using a different time window around the event. Our results on any of the two approaches do not change when we consider a two-year time window instead of the three-year one shown in the main results. Second, we estimate the separate effect of independent VCs (i.e., excluding captive VCs such as banks and corporate VCs). Captive VC investments are 84 (39.81\%) out of the total 211 PVC investments in our sample. Our results do not significantly change from those shown in the main analysis. Third, we estimate the effect by including all GVCs (i.e., not excluding government-supported VCs). Again, our results do not change significantly from those shown in the main analysis. All of these results are not shown for the sake of brevity but are available from the authors upon request.

\section{Discussion and conclusions}

In this work, we analyze the effect on employment growth of investments carried out by PVCs versus those completed by GOVCs before and during a period of economic crisis. We argue that the investments carried out by both PVCs and GOVCs should exert a positive impact on employment growth significantly higher than that on untreated matched companies in a period of normal economic activity. This result is to be expected for PVCs because they provide both funding and valuable non-financial value-adding services. In the case of GOVCs, we anticipate a significant positive effect because they also possess screening abilities (Guerini and Quas, 2015), which are valuable while their managers are not conditioned by government authorities in their investment decisions. Furthermore, GOVCs frequently invest in less developed areas, or in strategic sectors, that are most affected by information asymmetries. Hence, the funding received will surely have a significant impact on employment. Nevertheless, regarding the investments carried out during a period of crisis, we anticipate lower employment growth in 
companies backed by GOVCs, when compared to those backed by PVCs, because their managers may suffer from the pressure of government authorities to overcome the short-term effects of the crisis.

We test our hypotheses on the Spanish VC market because Spain was one of the economies that suffered most from the effects of the crisis in terms of financial constraints and firm closures, which led to a rapid increase in unemployment. Starting from the population of early-stage VC investments, we base our analyses on a sample of 384 young entrepreneurial ventures that received the first round of VC financing during the period 2005-2013, 173 of which from GOVCs and the remaining 211 from PVCs, and a control group of 888 non VCbacked entrepreneurial ventures.

Our results reveal that the investments of GOVCs have a higher impact on employment growth than those of PVCs (i.e., the average employment growth between t-3 and t+3 is 4 employees greater) in a period of normal economic activity, which is not what we expected according to our H1. This result could be explained by the different characteristics of companies in which both types of VCs invest in (i.e., GOVCs seem to invest more in labor-intensive industries and in areas most affected by information asymmetries). In addition, this result also endorses the screening abilities of GOVCs’ managers highlighted by Guerini and Quas (2015).

Conversely, companies backed by PVCs during the crisis grow significantly more that those funded before the onset of the crisis whereas the opposite is observed in the case on companies backed by GOVCs. This is in accordance with H2 and H3. As a result, we confirm that companies backed by PVCs during a period of crisis grow more than those backed by GOVCs, thus confirming our H4. The economic magnitude of this difference is an average of 3.3 employees more, in companies backed by PVCs, between t-3 and t+3. 
These findings could be attributed to the higher value added and monitoring exerted by PVCs during the crisis, when compared to that of GOVCs. PVCs' managers are better able to properly (and independently) screen, monitor and add value, even in adverse situations, than GOVCs. Since their matched control group firms do not have access to these valuable resources, the better performance of entrepreneurial ventures backed by PVCs should be even higher during a period of crisis. In contrast, we find lower employment growth in the case of the entrepreneurial ventures backed by GOVCs during a period of crisis. We argue that these results are possibly driven by the distortion coming from government officials in the investment process to overcome the short-term effects of the crisis. Their managers could be under pressure even to finance troubled firms to avoid firm closures.

From a policy perspective, GOVCs contribute to employment growth under normal economic conditions because their managers are able to screen properly companies affected by information asymmetries. Nevertheless, in a period of crisis, government officials may distort the investment activity of GOVCs to try to overcome the negative effects of the crisis on employment. GOVCs may end up doing things that have nothing to do with the fundamentals of VC finance. In this regard, government resources could be more efficiently allocated through the creation of a fund-of-funds, as suggested by Standaert and Manigart (2017), which participates in selected funds that effectively provide value added to their portfolio firms. Regarding the implications for PVCs, their managers' skills are specially endorsed in the case of investments carried out during a period of crisis.

This work contributes to the literature in several ways. First, it extends the existing evidence on the overall positive effect of VC finance on employment growth by focusing on the impact during a period of crisis. Furthermore, it provides evidence on the positive impact of GOVCs, at least on employment growth, under normal economic conditions. Second, it contributes to disentangling the effect on employment growth engendered by PVCs and 
GOVCs in their investees, providing evidence on the significant difference observed between both types of VCs during a period of crisis. Third, it also provides initial evidence on the limited effect of GOVCs in the case of investments carried out during a period of crisis.

Our study has some limitations that open the way for future research. First, our analysis is limited to the Spanish context. Spain presents a relatively well developed VC market (the fourth in terms of the amount invested) in Europe (Invest Europe, 2016) and is an interesting test-bed for our hypotheses. However, a replication of our study in other countries that also experienced a significant decline in employment as a result of the financial crisis would ensure the generalizability of our results. Second, it would be interesting to examine whether the beneficial effect provided by VCs in the crisis period is more pronounced for certain types of entrepreneurial ventures more subject to higher information asymmetries, such as younger and smaller companies, as well as those operating in high-technology industries. Finally, it would be interesting to analyze which factors affect the limited effectiveness of the investments of GOVCs during a period of crisis. 


\section{Acknowledgments}

We acknowledge financial assistance from the Spanish Ministry of Economics and Competitiveness (ECO2014-55674-R).

\section{References}

Admati, A.R., Pfleiderer, P., 1994. Robust financial contracting and the role of venture capitalists. J. Finance 49, 371-402. doi:10.1111/j.1540-6261.1994.tb05146.x

Alemany, L., Martí, J., 2005. Unbiased Estimation of Economic Impact of Venture Capital Backed Firms, SSRN Electronic Journal. doi:10.2139/ssrn.673341

Alférez, Á., 2018. Informe de actividad Venture Capital \& Private Equity en España. Madrid.

Alperovych, Y., Hübner, G., Lobet, F., 2015. How does governmental versus private venture capital backing affect a firm’s efficiency? Evidence from Belgium. J. Bus. Ventur. 30, 508-525. doi:10.1016/j.jbusvent.2014.11.001

Amit, R., Brander, J., Zott, C., 1998. Why do venture capital firms exist? theory and canadian evidence. J. Bus. Ventur. 13, 441-466. doi:10.1016/S08839026(97)00061-X

Arellano, M., Bond, S., 1991. Some tests of specification for panel data: Monte Carlo evidence and an application to employment equations. Rev. Econ. Stud. 58, 277297. doi:10.2307/2297968

Arellano, M., Bover, O., 1995. Another look at the instrumental variable estimation of error-components models. J. Econom. 68, 29-51. doi:10.1016/03044076(94)01642-D

Arthurs, J.D., Busenitz, L.W., 2006. Dynamic capabilities and venture performance: The effects of venture capitalists. J. Bus. Ventur. 21, 195-215. doi:10.1016/j.jbusvent.2005.04.004

Balboa, M., Martí, J., 2007. Factors That Determine the Reputation of Private Equity Managers in Developing Markets. J. Bus. Ventur. 22, 453-480. doi:10.1016/j.jbusvent.2006.05.004

Balboa, M., Martí, J., 2004. From Venture Capital to Private Equity. J. Priv. Equity 7, 54-63. doi:jpe.2004.391049

Balboa, M., Martí, J., Tresierra-Tanaka, Á., 2017. Are firms accessing venture funding more financially constrained? New evidence from capital structure adjustments. Eur. J. Financ. 23, 243-265. doi:10.1080/1351847X.2016.1151803

Balboa, M., Martí, J., Zieling, N., 2011. Impact of funding and value added on Spanish venture capital-backed firms. Innov. Eur. J. Soc. Sci. Res. 24, 449-466. doi:10.1080/13511610.2011.628827

Balboa, M., Martí, J., Zieling, N., 2007. Is the Spanish public sector effective in backing venture capital?, in: Gregoriou, G.N., Kooli, M., Kraeussl, R. (Eds.), Venture Capital in Europe. Elsevier B.V., Amsterdam, pp. 115-128. doi:10.1016/B978075068259-6.50012-9

Basel Committee on Banking Supervision, 2013. The liquidity coverage ratio and liquidity risk monitoring tools. Basel. 
Beck, T., Demirgüç-kunt, A., Martinez, M.S., 2008. Bank Financing for SMEs around the World. World Bank Policy Res. Work. Pap. n. 4785, 1-43.

Bergemann, D., Hege, U., 1998. Venture capital financing, moral hazard, and learning. J. Bank. Financ. 22, 703-735. doi:10.1016/S0378-4266(98)00017-X

Berger, A.N., Udell, G.F., 1998. The Economics of Small Business Finance : The Roles of Private Equity and Debt Markets in the Financial Growth Cycle. J. Bank. Financ. 22, 613-673. doi:10.1016/S0378-4266(98)00038-7

Bertoni, F., Colombo, M.G., Croce, A., 2010. The Effect of Venture Capital Financing on the Sensitivity to Cash Flow of Firm's Investments. Eur. Financ. Manag. 16, 528-551. doi:10.1111/j.1468-036X.2008.00463.x

Bertoni, F., Colombo, M.G., Grilli, L., 2011. Venture Capital Financing and the Growth of High-Tech Start-ups: Disentangling Treatment from Selection Effects. Res. Policy 40, 1028-1043. doi:10.1016/j.respol.2011.03.008

Bertoni, F., Ferrer, M.A., Martí, J., 2013. The Different Roles Played by Venture Capital and Private Equity Investors on the Investment Activity of their Portfolio Firms. Small Bus. Econ. 40, 607-633. doi:10.1007/s11187-011-9384-X

Bertoni, F., Tykvová, T., 2015. Does governmental venture capital spur invention and innovation? Evidence from young European biotech companies. Res. Policy 44, 925-935. doi:10.1016/j.respol.2015.02.002

Binks, M.R., Ennew, C.T., Reed, G. V., 1992. Information Asymmetries and the Provision of Finance to Small Firms. Int. Small Bus. J. 11, 35-46. doi:10.1177/026624269201100103

Blundell, R., Bond, S., 1998. Initial conditions and moment restrictions in dynamic panel data models. J. Econom. 87, 115-143. doi:10.1016/S0304-4076(98)00009-8

Brander, J.A., Du, Q., Hellmann, T.F., 2015. The Effects of Government-Sponsored Venture Capital: International Evidence. Rev. Financ. 19, 571-618. doi:10.1093/rof/rfu009

Brau, J.C., Brown, R.A., Osteryoung, J.S., 2004. Do Venture Capitalists Add Value to Small Manufacturing Firms? An Empirical Analysis of Venture and Nonventure Capital-Backed. J. Small Bus. Manag. 42, 78-92. doi:10.1111/j.1540627X.2004.00098.x

Brav, O., 2009. Access to capital, capital structure, and the funding of the firm. J. Finance 64, 263-308. doi:10.1111/j.1540-6261.2008.01434.x

Brown, J.D., Earle, J.S., 2017. Finance and Growth at the Firm Level: Evidence from SBA Loans. J. Finance 72, 1039-1080. doi:10.1111/jofi.12492

Bruton, G.D., Fried, V.H., Manigart, S., 2005. Institutional influences on the worldwide expansion of venture capital. Entrep. Theory Pract. 29, 737-760. doi:10.1111/j.1540-6520.2005.00106.x

Carpenter, R.E., Petersen, B.C., 2002. Is the Growth of Small Firms Constrained by Internal Finance? Rev. Econ. Stat. 84, 298-309. doi:10.1162/003465302317411541

Chemmanur, T.J., Krishnan, K., Nandy, D.K., 2011. How Does Venture Capital Financing Improve Efficiency in Private Firms? A look Beneath the Surface. Rev. Financ. Stud. 24, 4037-4090. doi:10.1093/rfs/hhr096 
Colombo, M.G., Cumming, D.J., Vismara, S., 2016. Governmental venture capital for innovative young firms. J. Technol. Transf. 41, 10-24. doi:10.1007/s10961-0149380-9

Conti, A., Dass, N., Graham, S.J.H., 2016. Venture Capital Investment Strategies under Financing Constraints: Evidence from the 2008 Financial Crisis (No. 2781674), Working Paper Series. doi:10.2139/ssrn.2781674

Cornelli, F., Yosha, O., 2003. Stage financing and there role of convertible securities. Rev. Econ. Stud. 70, 1-32. doi:10.1111/1467-937X.00235

Cowling, M., Liu, W., Ledger, A., 2012. Small business financing in the UK before and during the current financial crisis. Int. small Bus. J. 30, 778-800. doi:10.1177/0266242611435516

Criscuolo, C., Gal, P.N., Menon, C., 2014. The dynamics of employment growth: New evidence from 18 Countries (No. 14), Science, Technology and Industry Policy Papers. Paris. doi:10.1787/5jz417hj6hg6-en

Croce, A., Martí, J., 2016. Productivity Growth in Private-Equity-Backed Family Firms. Entrep. Theory Pract. 40, 657-683. doi:10.1111/etap.12138

Croce, A., Martí, J., Murtinu, S., 2013. The impact of venture capital on the productivity growth of European entrepreneurial firms: "Screening" or "value added” effect? J. Bus. Ventur. 28, 489-510. doi:10.1016/j.jbusvent.2012.06.001

Cumming, D.J., Grilli, L., Murtinu, S., 2017. Governmental and independent venture capital investments in Europe: A firm-level performance analysis. J. Corp. Financ. 42, 439-459. doi:10.1016/j.jcorpfin.2014.10.016

Cumming, D.J., MacIntosh, J.G., 2007. Mutual funds that invest in private equity? An analysis of labour-sponsored investment funds. Cambridge J. Econ. 31, 445-487. doi:10.1093/cje/bel041

Cumming, D.J., MacIntosh, J.G., 2006. Crowding out private equity: Canadian evidence. J. Bus. Ventur. 21, 569-609. doi:10.1016/j.jbusvent.2005.06.002

Cumming, D.J., Sapienza, H.J., Siegel, D.S., Wright, M., 2009. International entrepreneurship: Managerial and policy implications. Strateg. Entrep. J. 3, 283296. doi:10.1002/sej

Davila, A., Foster, G., Gupta, M., 2003. Venture Capital Financing and the Growth of Startup Firms. J. Bus. Ventur. 18, 689-708. doi:10.1016/S0883-9026(02)00127-1

Davis, A., 2011. Beyond the Banks. Innovative ways to finance Britain’s small businesses. London.

Engel, D., Keilbach, M., 2007. Firm-Level Implications of Early Stage Venture Capital Investment - An Empirical Investigation. J. Empir. Financ. 14, 150-167. doi:10.1016/j.jempfin.2006.03.004

Engel, D., Stiebale, J., 2014. Private Equity, Investment and Financial Constraints : Firm-Level Evidence for France and the United Kingdom. Small Bus. Econ. 43, 197-212. doi:10.1007/s11187-013-9530-8

European Commission, 2009. Economic Crisis in Europe: Causes, Consequences and Responses, European Economy. Office for Official Publications of the European Communities, Luxembourg. doi:10.1371/journal.pone.0016233 
Eurostat, 2016. Real GDP growth rate - volume [WWW Document]. URL http://ec.europa.eu/eurostat/tgm/table.do?tab=table\&init=1\&language=en\&pcode= tec00115\&plugin=1 (accessed 7.16.16).

Evans, D.S., 1987. The Relationship Between Firm Growth, Size, and Age: Estimates for 100 Manufacturing Industries. J. Ind. Econ. 35, 567-581.

Fama, E.F., Jensen, M.C., 1983. Agency problems and Residual Claims. J. Law Econ. 26, 327-349. doi:10.1086/467038

Gompers, P.A., 1995. Optimal Investment, Monitoring, and the Staging of Venture Capital. J. Finance 50, 1461-1489. doi:10.1111/j.1540-6261.1995.tb05185.x

Gorman, M., Sahlman, W.A., 1989. What do venture capitalists do? J. Bus. Ventur. 4, 231-248. doi:10.1016/0883-9026(89)90014-1

Grilli, L., Murtinu, S., 2014. Government, venture capital and the growth of European high-tech entrepreneurial firms. Res. Policy 43, 1523-1543. doi:10.1016/j.respol.2014.04.002

Guerini, M., Quas, A., 2015. Governmental venture capital in Europe: screening and certification. J. Bus. Ventur. 31, 175-195. doi:10.1016/j.jbusvent.2015.10.001

Hall, B.H., Lerner, J., 2010. The financing of R\&D and innovation, in: Hall, B.H., Rosemberg, N. (Eds.), Handbook of the Economics of Innovation. Elsevier B.V., Amsterdam, pp. 609-639.

Hellman, T., 1998. The allocation of control rights in venture capital contracts. RAND J. Econ. 29, 57-76. doi:10.2307/2555816

Hellmann, T., Puri, M., 2000. The Intercation Between Product Market and Financing Strategy: The Role of Venture Capital. Rev. Financ. Stud. 13, 959-984. doi:10.1093/rfs/13.4.959

Hochberg, Y. V., Ljungqvist, A., Lu, Y., 2007. Whom You Know Matters : Venture Capital Networks and Investment Performance. J. Finance 62, 251-301. doi:10.1111/j.1540-6261.2007.01207.x

Hsu, D.H., 2006. Venture Capitalists and Cooperative Start-up Commercialization Strategy. Manage. Sci. 52, 204-219. doi:10.1287/mnsc.1050.0480

Instituto Nacional de Estadística, 2016. Instituto Nacional de Estadística [WWW Document]. URL http://www.ine.es/dyngs/INEbase/es/categoria.htm?c=Estadistica_P\&cid=1254735 976595 (accessed 7.15.16).

Invest Europe, 2016. European Private Equity Activity Data 2007-2015 [WWW Document]. 6 May 2016. URL https://www.investeurope.eu/research/investeurope-publications/\#i (accessed 11.14.16).

Jääskeläinen, M., Maula, M., Seppä, T., 2006. Allocation of attention to portfolio companies and the performance of venture capital firms. Entrep. Theory Pract. 30, 185-206. doi:10.1111/j.1540-6520.2006.00117.x

Jensen, M.C., Meckling, W.H., 1976. Theory of the Firm : Managerial Behavior, Agency Costs and Ownership Structure. J. financ. econ. 3, 305-360. doi:10.1016/0304-405X(76)90026-X

Kanniainen, V., Keuschnigg, C., 2004. Start-up investment with scarce venture capital 
support. J. Bank. Financ. 28, 1935-1959. doi:10.1016/j.jbankfin.2003.07.005

Kaplan, S., Strömberg, P., 2003. Financial Contracting Theory Meets the Real World: Evidence from Venture Capital Contracts. Rev. Econ. Stud. 70, 281-315. doi:10.2307/3648635

Knockaert, M., Vanacker, T., 2013. The association between venture capitalists’ selection and value adding behavior: Evidence from early stage high tech venture capitalists. Small Bus. Econ. 40, 493-509. doi:10.1007/s11187-011-9378-8

Kortum, S., Lerner, J., 2000. Assessing the contribution of venture capital to innovation. RAND J. Econ. 31, 674-692. doi:10.2307/2696354

Leleux, B., Surlemont, B., 2003. Public versus private venture capital: Seeding or crowding out? A pan-European analysis. J. Bus. Ventur. 18, 81-104. doi:10.1016/S0883-9026(01)00078-7

Lerner, J., 2002. When Bureaucrats Meet Entrepreneurs: The Design of Effective “Public Venture Capital” Programmes. Econ. J. 112, F73-F84. doi:10.1111/14680297.00684

Lerner, J., 1999. The Government as Venture Capitalist: The Long-Run Impact of the SBIR Program. J. Bus. 72, 285-318. doi:10.1086/209616

Lerner, J., 1995. Venture Capitalists and the Oversight of Private Firms. J. Finance 50, 301-318. doi:10.1111/j.1540-6261.1995.tb05175.x

Luukkonen, T., Deschryvere, M., Bertoni, F., 2013. The value added by government venture capital funds compared with independent venture capital funds. Technovation 33, 154-162. doi:10.1016/j.technovation.2012.11.007

Manigart, S., Baeyens, K., Van Hyfte, W., 2002. The survival of venture capital backed companies. Ventur. Cap. 4, 103-124. doi:10.1080/13691060110103233

Martí, J., Balboa, M., 2006. Self-regulation in European venture capital and private equity markets. Int. J. Entrep. Innov. Manag. 6, 395-411. doi:10.1504/IJEIM.2006.010373

Mason, C.M., Harrison, R.T., 2015. Business angel investment activity in the financial crisis: UK evidence and policy implications. Environ. Plan. C Gov. Policy 33, 4360. doi:10.1068/c12324b

Megginson, W.L., Weiss, K.A., 1991. Venture Capitalist Certification in Initial Public Offerings. J. Finance 46, 879-903. doi:10.1111/j.1540-6261.1991.tb03770.xfr

Michaelas, N., Chittenden, F., Poutziouris, P., 1999. Financial Policy and Capital Structure Choice in U.K. SMEs: Empirical Evidence from Company Panel Data. Small Bus. Econ. 12, 113-130. doi:10.1023/A:1008010724051

Mills, K.G., McCarthy, B., 2014. The State of Small Business Lending: Credit Access during the Recovery and How Technology May Change the Game (No. 15-004). Boston.

Minola, T., Vismara, S., Hahn, D., 2017. Screening model for the support of governmental venture capital. J. Technol. Transf. 42, 59-77. doi:10.1007/s10961015-9461-4

Muzyka, D., Birley, S., Leleux, B., 1996. Trade-offs in the Investment Decisions of European Venture Capitalists. J. Bus. Ventur. 11, 273-287. doi:10.1016/0883- 
9026(95)00126-3

Myers, S.C., Majluf, N.S., 1984. Corporate Financing and Investment Decisions When Firms Have Information That Investors Do Not Have. J. financ. econ. 13, 187-221. doi:10.1016/0304-405X(84)90023-0

Ollivaud, P., Turner, D., 2015. The effect of the global financial-crisis on OECD potential output. OECD J. Econ. Stud. 2014, 41-60.

Paglia, J.K., Harjoto, M.A., 2014. The effects of private equity and venture capital on sales and employment growth in small and medium-sized businesses. J. Bank. Financ. 47, 177-197. doi:10.1016/j.jbankfin.2014.06.023

Puri, M., Zarutskie, R., 2012. On the Life Cycle Dynamics of Venture-Capital- and Non-Venture-Capital-Financed Firms. J. Finance 67, 2247-2293. doi:10.1111/j.1540-6261.2012.01786.x

Sahlman, W.A., 1990. The structure and governance of venture-capital organizations. J. financ. econ. 27, 473-521. doi:10.1016/0304-405X(90)90065-8

Sapienza, H., Manigart, S., Vermeir, W., 1996. Venture capitalist governance and value added in four countries. J. Bus. Ventur. 11, 439-469. doi:10.1016/S08839026(96)00052-3

Sørensen, M., 2007. How Smart Is Smart Money? A Two-sided Matching Model of Venture Capital. J. Finance 62, 2725-2762. doi:10.1111/j.1540-6261.2007.01291.x

Standaert, T., Manigart, S., 2017. Government as fund-of-fund and VC fund sponsors: effect on employment in portfolio companies. Small Bus. Econ. doi:10.1007/s11187-016-9831-9

Sutton, J., 1997. Gibrat’s Legacy. J. Econ. Lit. 35, 40-59. doi:10.2307/2729692

Tian, X., 2012. The role of venture capital syndication in value creation for entrepreneurial firms. Rev. Financ. 16, 245-283. doi:10.1093/rof/rfr019

Tyebjee, T.T., Bruno, A. V., 1984. A model of venture capitalist investment activity. Manage. Sci. 30, 1051-1066. doi:10.1287/mnsc.30.9.1051

van den Pol, A.C., 2016. The Effect of the Financial Crisis on Venture Capital-backed Firms An Empirical Study on the VC Industry' s Function and its Investees. Erasmus University.

Webcapitalriesgo, 2016. Venture capital and private equity investments [WWW Document]. URL https://www.webcapitalriesgo.com/dos.php?idioma=ES\&activo=M5 (accessed 7.16.16).

Wilson, K., 2015. Policy lessons from financing young entrepreneurial firms. Paris. doi:10.1787/5js03z8zrh9p-en

Windmeijer, F., 2005. A finite sample correction for the variance of linear efficient twostep GMM estimators. J. Econom. 126, 25-51. doi:10.1016/j.jeconom.2004.02.005

Young, B., 2014. Financial crisis: Causes, policy responses, future challenges. Brussels. doi:10.2777/65531 
Figure 1. Evolution of annual Spanish GDP growth between 2004 and 2014

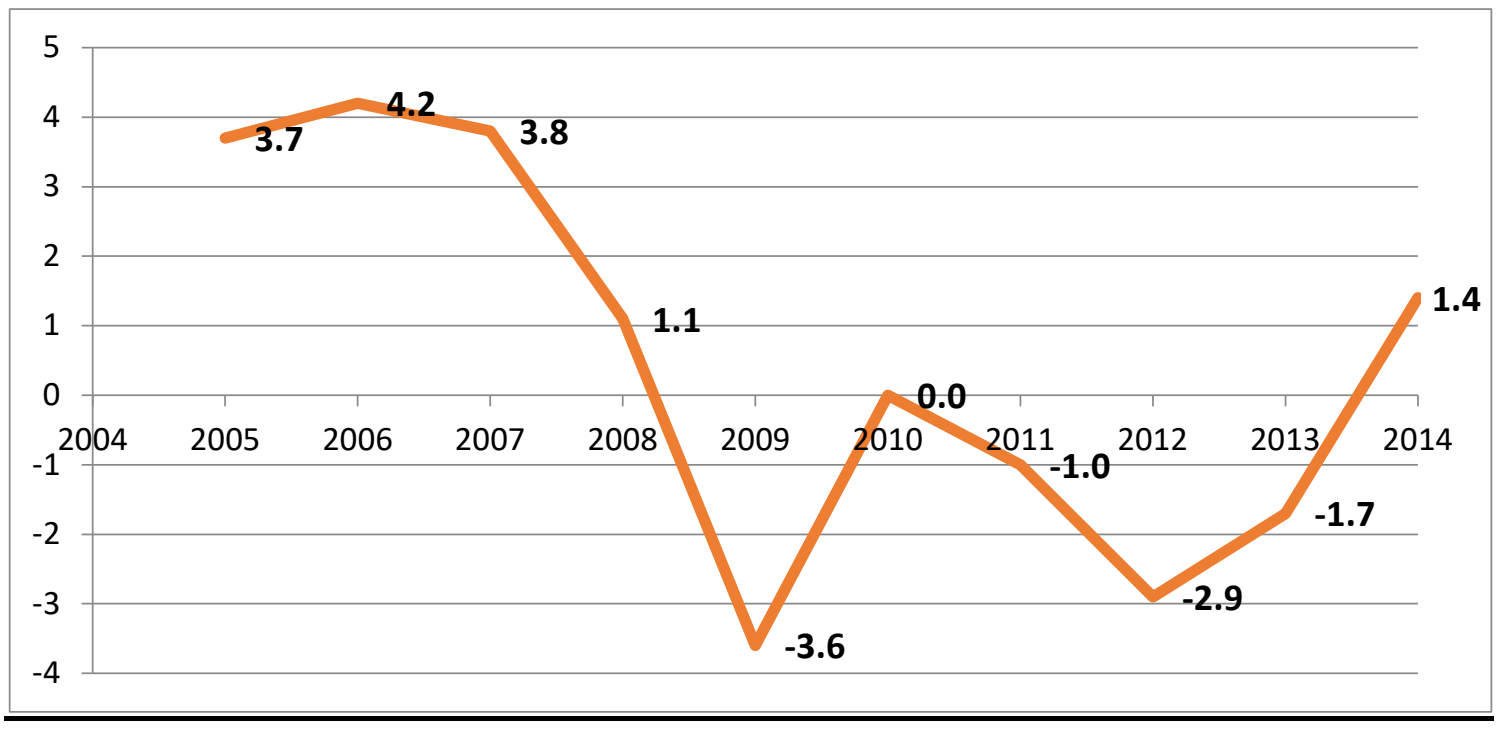

Source: Eurostat (2016). 


\section{TABLES}

Table 1. Number of VC investments in Spain by year and activity sector

\begin{tabular}{|c|c|c|c|c|c|c|c|c|c|c|c|c|c|}
\hline & 2005 & 2006 & 2007 & 2008 & 2009 & 2010 & 2011 & 2012 & 2013 & $\begin{array}{l}\text { Total } \\
\text { GVCs }\end{array}$ & $\%$ & $\begin{array}{l}\text { Total } \\
\text { PVCs } \\
\end{array}$ & $\%$ \\
\hline Agriculture & 1 & 3 & 1 & 5 & 2 & & 5 & & & 17 & $2,6 \%$ & 8 & $0,7 \%$ \\
\hline Industrial Products and Services & 12 & 17 & 15 & 13 & 17 & 10 & 7 & 6 & 5 & 102 & $15,7 \%$ & 52 & $4,9 \%$ \\
\hline Consumer products & 7 & 8 & 2 & 6 & 4 & 4 & 2 & 2 & 5 & 40 & $6,2 \%$ & 38 & $3,6 \%$ \\
\hline Construction & 1 & 2 & 1 & 2 & 2 & 1 & & 1 & 2 & 12 & $1,8 \%$ & 5 & $0,5 \%$ \\
\hline Leisure, hotels and restaurants & 1 & 4 & 6 & 6 & 4 & 2 & 3 & 1 & 5 & 32 & $4,9 \%$ & 19 & $1,8 \%$ \\
\hline Other services & 4 & 6 & 9 & 11 & 12 & 7 & 4 & 9 & 4 & 66 & $10,2 \%$ & 57 & $5,3 \%$ \\
\hline Other & & & 2 & 1 & 3 & 1 & 1 & 1 & & 9 & $1,4 \%$ & 9 & $0,8 \%$ \\
\hline Subtotal labor-intensive & 26 & 40 & 36 & 44 & 44 & 25 & 22 & 20 & 21 & 278 & $42,8 \%$ & 188 & $17,6 \%$ \\
\hline ICT & 12 & 23 & 17 & 16 & 19 & 16 & 9 & 12 & 15 & 139 & $21,4 \%$ & 562 & $52,7 \%$ \\
\hline Biotechnology & 8 & 11 & 15 & 12 & 15 & 13 & 6 & 4 & 6 & 90 & $13,8 \%$ & 122 & $11,4 \%$ \\
\hline Healthcare & 1 & 5 & 5 & 2 & 7 & 3 & 2 & 4 & 2 & 31 & $4,8 \%$ & 63 & $5,9 \%$ \\
\hline Electronic components & 1 & 5 & 1 & 2 & 5 & 2 & & & & 16 & $2,5 \%$ & 22 & $2,1 \%$ \\
\hline Energy & 1 & 11 & 7 & 9 & 4 & 6 & 3 & & & 41 & $6,3 \%$ & 55 & $5,2 \%$ \\
\hline Chemicals and materials & 6 & 5 & 8 & 3 & 4 & 1 & 1 & 2 & & 30 & $4,6 \%$ & 16 & $1,5 \%$ \\
\hline Industrial Automation & 1 & 1 & 1 & 2 & 3 & 3 & 1 & & 1 & 13 & $2,0 \%$ & 12 & $1,1 \%$ \\
\hline Transportation & & & 1 & 2 & 1 & & 1 & & 1 & 6 & $0,9 \%$ & 11 & $1,0 \%$ \\
\hline Financial services & 2 & 1 & 1 & 1 & 1 & & & & & 6 & $0,9 \%$ & 16 & $1,5 \%$ \\
\hline Subtotal capital-intensive & 32 & 62 & 56 & 49 & 59 & 44 & 23 & 22 & 25 & 372 & $57,2 \%$ & 879 & $82,4 \%$ \\
\hline Total & 58 & 102 & 92 & 93 & 103 & 69 & 45 & 42 & 46 & 650 & $100,0 \%$ & 1,067 & $100,0 \%$ \\
\hline
\end{tabular}

Note: This is the total number of new investments not discounting duplicates caused by syndication or secondary buyouts.

Source: ASCRI/Webcapitalriesgo. 
Table 2. Sample composition

\begin{tabular}{lcccccccc}
\hline Foundation Year & \multicolumn{2}{c}{ CG } & \multicolumn{2}{c}{ VC } & \multicolumn{2}{c}{ GOVC } & \multicolumn{2}{c}{ PVC } \\
$2000-2002$ & 129 & $14.53 \%$ & 30 & $7.81 \%$ & 18 & $10.40 \%$ & 12 & $5.69 \%$ \\
$2003-2005$ & 222 & $25.00 \%$ & 117 & $30.47 \%$ & 59 & $34.10 \%$ & 58 & $27.49 \%$ \\
$2006-2008$ & 313 & $35.25 \%$ & 134 & $34.90 \%$ & 65 & $37.57 \%$ & 69 & $32.70 \%$ \\
$2009-2012$ & 224 & $25.23 \%$ & 103 & $26.82 \%$ & 31 & $17.92 \%$ & 72 & $34.12 \%$ \\
Total & 888 & $100 \%$ & 384 & $100 \%$ & 173 & $100 \%$ & 211 & $100 \%$
\end{tabular}

\begin{tabular}{|c|c|c|c|c|c|c|c|c|}
\hline \multirow{2}{*}{$\begin{array}{l}\text { Activity Sector } \\
\text { Commerce }\end{array}$} & \multicolumn{2}{|c|}{ CG } & \multicolumn{2}{|c|}{ VC } & \multicolumn{2}{|c|}{ GOVC } & \multicolumn{2}{|c|}{ PVC } \\
\hline & 103 & $11.60 \%$ & 37 & $9.64 \%$ & 10 & $5.78 \%$ & 27 & $12.80 \%$ \\
\hline ICT & 181 & $20.38 \%$ & 77 & $20.05 \%$ & 20 & $11.56 \%$ & 57 & $27.01 \%$ \\
\hline Manufacturing & 177 & $19.93 \%$ & 66 & $17.19 \%$ & 41 & $23.70 \%$ & 25 & $11.85 \%$ \\
\hline Other Services & 248 & $27.93 \%$ & 126 & $32.81 \%$ & 64 & $36.99 \%$ & 62 & $29.38 \%$ \\
\hline Pharma \& R\&D & 160 & $18.02 \%$ & 66 & $17.19 \%$ & 32 & $18.50 \%$ & 34 & $16.11 \%$ \\
\hline Primary \& Utilities & 19 & $2.14 \%$ & 12 & $3.13 \%$ & 6 & $3.47 \%$ & 6 & $2.84 \%$ \\
\hline Total & 888 & $100 \%$ & 384 & $100 \%$ & 173 & $100 \%$ & 211 & $100 \%$ \\
\hline Region & \multicolumn{2}{|c|}{ CG } & \multicolumn{2}{|c|}{ VC } & \multicolumn{2}{|c|}{ GOVC } & \multicolumn{2}{|c|}{ PVC } \\
\hline Andalusia & 101 & $11.37 \%$ & 61 & $15.89 \%$ & 58 & $33.53 \%$ & 3 & $1.42 \%$ \\
\hline Aragon & 23 & $2.59 \%$ & 12 & $3.13 \%$ & 8 & $4.62 \%$ & 4 & $1.90 \%$ \\
\hline Asturias & 35 & $3.94 \%$ & 12 & $3.13 \%$ & 12 & $6.94 \%$ & 0 & $0.00 \%$ \\
\hline Baleares & 5 & $0.56 \%$ & 1 & $0.26 \%$ & 0 & $0.00 \%$ & 1 & $0.47 \%$ \\
\hline Canarias & 2 & $0.23 \%$ & 1 & $0.26 \%$ & 0 & $0.00 \%$ & 1 & $0.47 \%$ \\
\hline Cantabria & 3 & $0.34 \%$ & 1 & $0.26 \%$ & 0 & $0.00 \%$ & 1 & $0.47 \%$ \\
\hline Castile - La Mancha & 14 & $1.58 \%$ & 6 & $1.56 \%$ & 4 & $2.31 \%$ & 2 & $0.95 \%$ \\
\hline Castile - Leon & 21 & $2.36 \%$ & 7 & $1.82 \%$ & 0 & $0.00 \%$ & 7 & $3.32 \%$ \\
\hline Catalonia & 272 & $30.63 \%$ & 124 & $32.29 \%$ & 23 & $13.29 \%$ & 101 & $47.87 \%$ \\
\hline Community of Valencia & 43 & $4.84 \%$ & 19 & $4.95 \%$ & 0 & $0.00 \%$ & 19 & $9.00 \%$ \\
\hline Extremadura & 23 & $2.59 \%$ & 9 & $2.34 \%$ & 8 & $4.62 \%$ & 1 & $0.47 \%$ \\
\hline Galicia & 35 & $3.94 \%$ & 15 & $3.91 \%$ & 13 & $7.51 \%$ & 2 & $0.95 \%$ \\
\hline La Rioja & 5 & $0.56 \%$ & 2 & $0.52 \%$ & 0 & $0.00 \%$ & 2 & $0.95 \%$ \\
\hline Madrid & 173 & $19.48 \%$ & 58 & $15.10 \%$ & 5 & $2.89 \%$ & 53 & $25.12 \%$ \\
\hline Murcia & 3 & $0.34 \%$ & 1 & $0.26 \%$ & 0 & $0.00 \%$ & 1 & $0.47 \%$ \\
\hline Navarra & 50 & $5.63 \%$ & 18 & $4.69 \%$ & 12 & $6.94 \%$ & 6 & $2.84 \%$ \\
\hline Basque Country & 80 & $9.01 \%$ & 37 & $9.64 \%$ & 30 & $17.34 \%$ & 7 & $3.32 \%$ \\
\hline Total & 888 & $100 \%$ & 384 & $100 \%$ & 173 & $100 \%$ & 211 & $100 \%$ \\
\hline
\end{tabular}

This Table reports the sample composition by foundation year, activity sector and region. CG: Control group of non VC-backed companies; VC: Venture capital-backed companies; PVC: Private venture capitalbacked companies; GOVC: Governmental venture capital-backed companies. 
Table 3. Descriptive statistics

\begin{tabular}{|c|c|c|c|c|c|c|c|c|}
\hline Region & \multicolumn{2}{|c|}{ CG } & \multicolumn{2}{|c|}{ VC } & \multicolumn{2}{|c|}{ GOVC } & \multicolumn{2}{|c|}{ PVC } \\
\hline Developed region & 651 & $73.31 \%$ & 271 & $70.57 \%$ & 78 & $45.09 \%$ & 193 & $91.47 \%$ \\
\hline Underdeveloped region & 237 & $26.69 \%$ & 113 & $29.43 \%$ & 95 & $54.91 \%$ & 18 & $8.53 \%$ \\
\hline Total & 888 & $100 \%$ & 384 & $100 \%$ & 173 & $100 \%$ & 211 & $100 \%$ \\
\hline $\begin{array}{l}\text { Size at the time of } \\
\text { VC financing/ matching }\end{array}$ & \multicolumn{2}{|c|}{ CG } & \multicolumn{2}{|c|}{ VC } & \multicolumn{2}{|c|}{ GOVC } & \multicolumn{2}{|c|}{ PVC } \\
\hline Small firms & 430 & $48.42 \%$ & 157 & $40.89 \%$ & 81 & $46.82 \%$ & 76 & $36.02 \%$ \\
\hline Large firms & 458 & $51.58 \%$ & 227 & $59.11 \%$ & 92 & $53.18 \%$ & 135 & $63.98 \%$ \\
\hline Total & 888 & $100 \%$ & 384 & $100 \%$ & 173 & $100 \%$ & 211 & $100 \%$ \\
\hline VC Year/matching & \multicolumn{2}{|c|}{ CG } & \multicolumn{2}{|c|}{ VC } & \multicolumn{2}{|c|}{ GOVC } & \multicolumn{2}{|c|}{ PVC } \\
\hline 2005-2008 & 434 & $48.87 \%$ & 175 & $45.57 \%$ & 86 & $49.71 \%$ & 89 & $42.18 \%$ \\
\hline 2009-2013 & 454 & $51.13 \%$ & 209 & $54.43 \%$ & 87 & $50.29 \%$ & 122 & $57.82 \%$ \\
\hline Total & 888 & $100 \%$ & 384 & $100 \%$ & 173 & $100 \%$ & 211 & $100 \%$ \\
\hline
\end{tabular}

This Table reports the distribution of the sample by type of region (developed versus underdeveloped regions), size at the time of investment (based on the median sales figure at the time of matching), and period of the VC investment (pre-crisis and during the crisis).

Source: ASCRI/Webcapitalriesgo and Orbis. 


\section{Table 4. Correlation matrix}

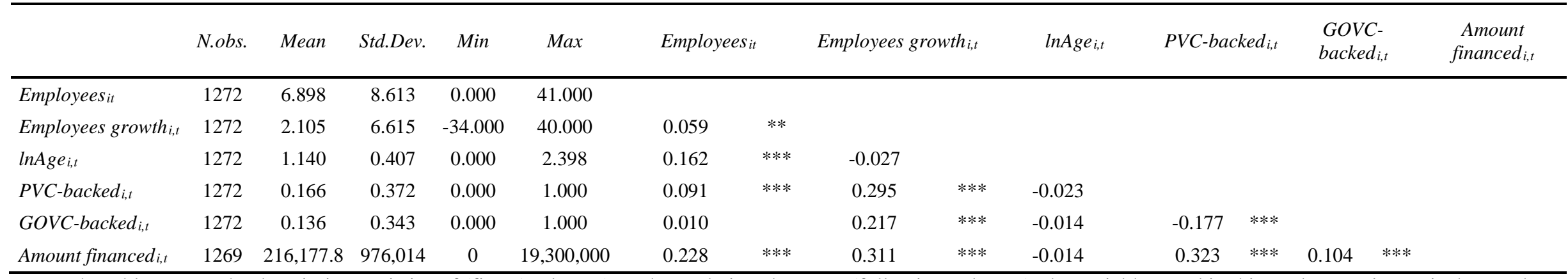

Note: The tables report the descriptive statistics of (first 5 columns), and correlations between (following columns), the variables used in this study. Employees is the number of a firm's employees. Employees growth is calculated as the difference between the average number of employees in the three years after the event and the average number of employees in the three years before the event. PVC-backed is a dummy variable equal to 1 after a firm receives a funding from a PVCs. GOVC-backed is a dummy variable equal to 1 after a firm receives a funding from a GOVCs. Amount financed is the amount (in million Euro) a firm receives from a VC in a given year. lnAge is the logarithm of firm's age (in years). *** indicates correlations significant at the $1 \%$ level. **denotes significance at $5 \%$ level. 
Table 5. Univariate analysis

\begin{tabular}{|c|c|c|c|c|}
\hline & CG & VC & $\begin{array}{r}\text { Difference } \\
\text { vs. CG } \\
\end{array}$ & VC \\
\hline \multirow[t]{2}{*}{ Employment size at matching } & 1.567 & 1.623 & 0.056 & \\
\hline & $(0.028)$ & $(0.045)$ & $(0.053)$ & \\
\hline \multirow[t]{2}{*}{ Employment size at matching in the years before crisis } & 1.591 & 1.676 & 0.085 & \\
\hline & $(0.039)$ & $(0.065)$ & $(0.076)$ & \\
\hline \multirow[t]{2}{*}{ Employment size at matching in the years of crisis } & 1.545 & 1.580 & 0.035 & \\
\hline & $(0.042)$ & $(0.062)$ & $(0.075)$ & \\
\hline \multirow[t]{2}{*}{ Employment size after matching } & 1.572 & 2.270 & 0.697 & $* * *$ \\
\hline & $(0.013)$ & $(0.022)$ & $(0.026)$ & \\
\hline \multirow[t]{2}{*}{ Employment size after matching in the years before crisis } & 1.742 & 2.222 & 0.480 & $* * *$ \\
\hline & $(0.035)$ & $(0.057)$ & $(0.067)$ & \\
\hline \multirow[t]{2}{*}{ Employment size after matching in the years of crisis } & 1.548 & 2.277 & 0.729 & $* * *$ \\
\hline & $(0.015)$ & $(0.024)$ & $(0.028)$ & \\
\hline
\end{tabular}

Note: The table reports the average Ln(Employees) of treated companies and companies matched using a propensity score at the time of matching (i.e., average between t-1 and $t$ ), and after matching. Difference is the difference in Ln(Employees) between treated and matched companies. Standard errors are in round brackets. $* * *$ denotes significance at $1 \%$ level 
Table 6. Employment growth in entrepreneurial ventures funded by PVCs and GOVCs before and during the crisis: PSM results

Panel A. Regression results.

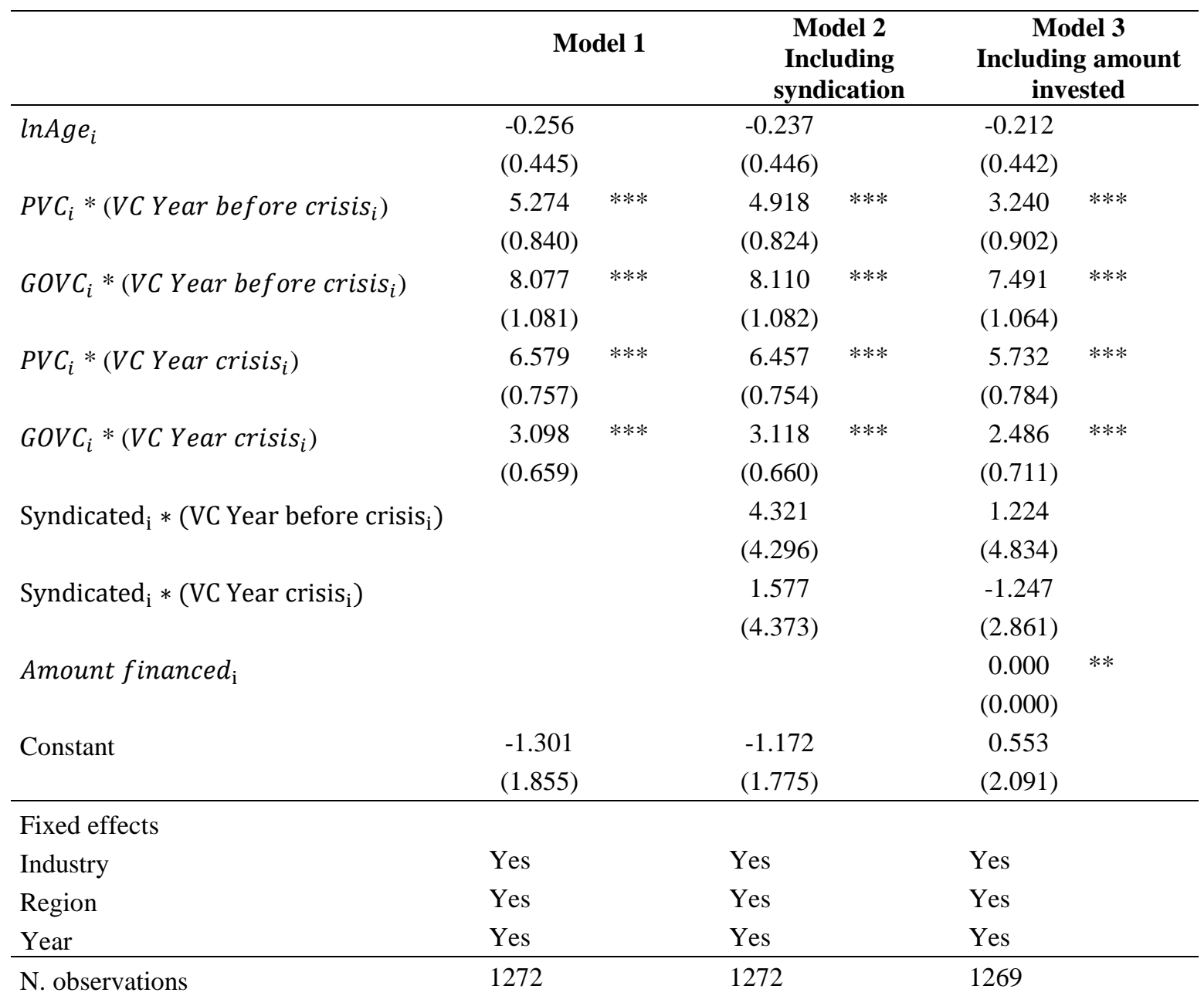

Panel A reports the effects of the two types of VC on the employment growth of invested companies estimated through propensity score matching. The dependent variable $\Delta$ Employees $_{i}$ is calculated as the difference between the average number of employees in the three years after the event and the average number of employees in the three years before the event. $\ln A g e_{i, t}$ is the natural logarithm of the company's age (i.e., number of years since its foundation). VC Year crisis $_{i}$ is a dummy variable taking value 1 if a VC-backed company receives financing from 2009 to 2013, and 0 if the year of VC financing is from 2005 until 2008. VC Year before crisis $s_{i}$ is defined as $\left(1-\mathrm{VC}\right.$ Year $\left.\mathrm{crisis}_{\mathrm{i}}\right) . P V C_{i}$ is a dummy taking the value 1 for companies invested by a PVCs. $G O V C_{i}$ is a dummy taking the value 1 for companies backed by a GOVCs. Amount financed fis $_{i}$ is amount financed by the investor to the invested company. Syndicated ${ }_{i}$ is a dummy variable taking value 1 if GOVCs and PVCs coinvest in the specific company. The models include time, region and industry dummies. Standard errors are reported in parentheses.

*** denotes significance at the $1 \%$ level. $* *$ denotes significance at the $5 \%$ level. 
Panel B. Wald tests. Differences between PVCs and GOVCs

\begin{tabular}{|c|c|c|c|c|c|c|}
\hline & \multicolumn{2}{|c|}{ Model 1} & \multicolumn{2}{|c|}{ Model 2} & \multicolumn{2}{|c|}{ Model 3} \\
\hline $\begin{array}{l}\text { Difference between PVCs and GOVCs } \\
\text { (investment in the years before crisis) }\end{array}$ & $\begin{array}{l}-2.803 \\
(1.322)\end{array}$ & $* *$ & $\begin{array}{l}-3.193 \\
(1.319)\end{array}$ & $* *$ & $\begin{array}{l}-4.251 \\
(1.289)\end{array}$ & $* * *$ \\
\hline $\begin{array}{l}\text { Difference between PVCs and GOVCs } \\
\text { (investment in the years of crisis) }\end{array}$ & $\begin{array}{c}3.481 \\
(0.968)\end{array}$ & $* * *$ & $\begin{array}{c}3.339 \\
(0.972)\end{array}$ & $* * *$ & $\begin{array}{c}3.246 \\
(0.932)\end{array}$ & $* * *$ \\
\hline
\end{tabular}

Panel B reports the results of the Wald test described in Section 3.3 in order to test the differences in employment growth among companies invested by PVCs and GOVCs before and during the crisis. *** denote significance at the $1 \%$ level. ${ }^{* *}$ denote significance at the $5 \%$ level.

Panel C. Wald tests. Effect of the crisis on the impact of PVCs and GOVCs

\begin{tabular}{lcccc}
\hline & Model 1 & Model 2 & Model 3 \\
\hline Impact of PVCs: post-crisis versus before crisis & 1.305 & 1.540 & $2.492 \quad * *$ \\
& $(1.127)$ & $(1.111)$ & $(1.088)$ \\
Effect of GOVCs: post-crisis versus before crisis & -4.979 & $* * *$ & $-4.992 \quad * * *$ & $-5.005 \quad * * *$ \\
& $(1.230)$ & $(1.231)$ & $(1.184)$ \\
\hline
\end{tabular}

Panel C reports the results of the Wald test described in Section 3.3 in order to test changes in the impact of investments carried out by PVCs and GOVCs during the crisis versus the impact of investment done before the crisis started. *** denotes significance at the $1 \%$ level. ** denotes significance at the $5 \%$ level. 
Table 7. Employment growth in entrepreneurial ventures funded by PVCs and GOVCs before and during the crisis: 2SLS results

Panel A. Regression results.

\begin{tabular}{|c|c|c|c|c|c|c|}
\hline & \multicolumn{2}{|c|}{ Model 1} & \multicolumn{2}{|c|}{$\begin{array}{c}\text { Model } 2 \\
\text { Including } \\
\text { syndication }\end{array}$} & \multicolumn{2}{|c|}{$\begin{array}{c}\text { Model } 3 \\
\text { Including amount } \\
\text { invested }\end{array}$} \\
\hline $\ln A g e_{i}$ & $\begin{array}{l}-0.071 \\
(0.472)\end{array}$ & & $\begin{array}{l}-0.062 \\
(0.47)\end{array}$ & & $\begin{array}{l}-0.047 \\
(0.462)\end{array}$ & \\
\hline VC Year crisis $_{i}$ & $\begin{array}{l}-0.283 \\
(0.986)\end{array}$ & & $\begin{array}{l}-0.226 \\
(0.982)\end{array}$ & & $\begin{array}{l}-0.274 \\
(0.960)\end{array}$ & \\
\hline$\left.P V C_{i} *(V C \text { Year before crisis })_{i}\right)$ & $\begin{array}{c}8.811 \\
(3.382)\end{array}$ & $* * *$ & $\begin{array}{c}8.296 \\
(3.381)\end{array}$ & $* *$ & $\begin{array}{c}6.362 \\
(3.385)\end{array}$ & $*$ \\
\hline $\begin{array}{l}G O V C_{i} * \\
\left(V C \text { Year before } \text { crisis }_{i}\right)\end{array}$ & $\begin{array}{l}11.563 \\
(3.341)\end{array}$ & $* * *$ & $\begin{array}{l}11.433 \\
(3.328)\end{array}$ & $* * *$ & $\begin{array}{l}10.558 \\
(3.322)\end{array}$ & $* * *$ \\
\hline$P V C_{i} *\left(V C\right.$ Year crisis $\left._{i}\right)$ & $\begin{array}{l}10.091 \\
(3.344)\end{array}$ & $* * *$ & $\begin{array}{c}9.803 \\
(3.333)\end{array}$ & $* * *$ & $\begin{array}{c}8.814 \\
(3.321)\end{array}$ & $* * *$ \\
\hline GOVC $\left._{i} *(\text { VC Year crisis })_{i}\right)$ & $\begin{array}{c}6.565 \\
(3.326)\end{array}$ & $* *$ & $\begin{array}{c}6.423 \\
(3.313)\end{array}$ & * & $\begin{array}{c}5.530 \\
(3.300)\end{array}$ & $*$ \\
\hline $\begin{array}{l}\text { Syndicated }_{\mathrm{i}} * \\
(\text { VC Year before crisis } \\
\text { ( ) }\end{array}$ & & & $\begin{array}{c}4.238 \\
(2.308)\end{array}$ & $*$ & $\begin{array}{c}1.144 \\
(2.306)\end{array}$ & \\
\hline Syndicated $_{\mathrm{i}} *\left(\right.$ VC Year crisis $\left._{\mathrm{i}}\right)$ & & & $\begin{array}{c}1.605 \\
(2.146)\end{array}$ & & $\begin{array}{l}-1.220 \\
(2.139)\end{array}$ & \\
\hline Amount financed $\mathrm{i}_{\mathrm{i}}$ & & & & & $\begin{array}{c}0.000 \\
(0.000)\end{array}$ & $* * *$ \\
\hline Constant & $\begin{array}{l}-0.668 \\
(2.124)\end{array}$ & & $\begin{array}{l}-0.698 \\
(2.115)\end{array}$ & & $\begin{array}{l}-0.516 \\
(2.096)\end{array}$ & \\
\hline Fixed effects & & & & & & \\
\hline Industry & Yes & & Yes & & Yes & \\
\hline Region & Yes & & Yes & & Yes & \\
\hline Year & Yes & & Yes & & Yes & \\
\hline N. observations & 1272 & & 1272 & & 1269 & \\
\hline
\end{tabular}

Panel A reports the effects of the two types of VC on the employment growth of invested companies estimated through two-stage least squares. The dependent variable $\Delta$ Employees $_{i}$ is calculated as the difference between the average number of employees in the three years after the event and the average number of employees in the three years before the event. $\ln A g e_{i, t}$ is the natural logarithm of the company's age (i.e., number of years since its foundation). $V C$ Year crisis $_{i}$ is a dummy variable taking value 1 if a VC-backed company receives financing from 2009 to 2013, and 0 if the year of VC financing is from 2005 until 2008. VC Year before crisis $_{i}$ is defined as $\left(1-\mathrm{VC}\right.$ Year $\left.\mathrm{crisis}_{\mathrm{i}}\right) . P V C_{i}$ is a dummy taking the value 1 for companies invested by a PVCs. GOVC $C_{i}$ is a dummy taking the value 1 for companies backed by a GOVCs. Amount financed $_{i}$ is the amount financed by the investor to the invested company. Syndicated $_{i}$ is a dummy variable taking value 1 if GOVCs and PVCs co-invest in the specific company. The models include time, region and industry dummies. The instrumental variable for the two-stage least squares method is the number of VC investments in the three years before the time in which the focal company receives the financing. Standard errors are reported in parentheses.

*** denotes significance at the $1 \%$ level. $* *$ denotes significance at the $5 \%$ level. 
Panel B. Wald tests. Differences between PVCs and GOVCs

\begin{tabular}{|c|c|c|c|c|c|c|}
\hline \multirow[b]{2}{*}{$\begin{array}{l}\text { Difference between PVCs and GOVCs } \\
\text { (investment in the years before crisis) }\end{array}$} & \multicolumn{2}{|c|}{ Model 1} & \multicolumn{2}{|c|}{$\begin{array}{c}\text { Model } 2 \\
\text { Including } \\
\text { syndication } \\
\end{array}$} & \multicolumn{2}{|c|}{$\begin{array}{c}\text { Model } 3 \\
\text { Including } \\
\text { amount invested }\end{array}$} \\
\hline & $\begin{array}{l}-2.752 \\
(0.919)\end{array}$ & $* * *$ & $\begin{array}{l}-3.137 \\
(0.942)\end{array}$ & $* * *$ & $\begin{array}{l}-4.195 \\
(0.941)\end{array}$ & $* * *$ \\
\hline $\begin{array}{l}\text { Difference between PVCs and GOVCs } \\
\text { (investment in the years of crisis) }\end{array}$ & $\begin{array}{c}3.525 \\
(0.899)\end{array}$ & $* * *$ & $\begin{array}{c}3.380 \\
(0.911)\end{array}$ & $* * *$ & $\begin{array}{c}3.283 \\
(0.894)\end{array}$ & $* * *$ \\
\hline
\end{tabular}

Panel B reports the results of the Wald test described in Section 3.3 in order to test the differences in employment growth among companies invested by PVCs and GOVCs before and during the crisis.

*** denotes significance at the $1 \%$ level.

Panel C. Wald tests. Effect of the crisis on the impact of PVCs and GOVCs

\begin{tabular}{|c|c|c|c|c|c|c|}
\hline \multirow[b]{2}{*}{$\begin{array}{l}\text { Impact of PVCs: post-crisis versus } \\
\text { before crisis }\end{array}$} & \multicolumn{2}{|c|}{ Model 1} & \multicolumn{2}{|c|}{$\begin{array}{c}\text { Model } 2 \\
\text { Including } \\
\text { syndication }\end{array}$} & \multicolumn{2}{|c|}{$\begin{array}{c}\text { Model } 3 \\
\text { Including } \\
\text { amount invested }\end{array}$} \\
\hline & $\begin{array}{c}1.279 \\
(0.911)\end{array}$ & & $\begin{array}{l}1.507 \\
(0.939)\end{array}$ & & $\begin{array}{c}2.452 \\
(0.934)\end{array}$ & $* * *$ \\
\hline $\begin{array}{l}\text { Effect of GOVCs: post-crisis versus before } \\
\text { crisis }\end{array}$ & $\begin{array}{l}-4.997 \\
(0.985)\end{array}$ & $* * *$ & $\begin{array}{l}-5.009 \\
(0.985)\end{array}$ & $* * *$ & $\begin{array}{l}-5.027 \\
(0.968)\end{array}$ & $* * *$ \\
\hline
\end{tabular}

Panel D. First stage regression. Probability to receive VC

\begin{tabular}{|c|c|c|c|c|c|c|}
\hline \multirow[b]{2}{*}{${\ln A g e_{i}}_{i}$} & \multicolumn{2}{|c|}{ Model 1} & \multicolumn{2}{|c|}{$\begin{array}{c}\text { Model } 2 \\
\text { Including } \\
\text { syndication }\end{array}$} & \multicolumn{2}{|c|}{$\begin{array}{c}\text { Model } 3 \\
\begin{array}{c}\text { Including amount } \\
\text { invested }\end{array} \\
\end{array}$} \\
\hline & $\begin{array}{l}1.855 \\
(0.583)\end{array}$ & $* * *$ & $\begin{array}{l}1.855 \\
(0.583)\end{array}$ & $* * *$ & $\begin{array}{l}1.800 \\
(0.583)\end{array}$ & $* * *$ \\
\hline $\ln A g e_{i}^{2}$ & $\begin{array}{l}-0.833 \\
(0.24)\end{array}$ & $* * *$ & $\begin{array}{l}-0.833 \\
(0.24)\end{array}$ & $* * *$ & $\begin{array}{l}-0.811 \\
(0.239)\end{array}$ & $* * *$ \\
\hline VC Year crisis & $\begin{array}{l}0.149 \\
(0.201)\end{array}$ & & $\begin{array}{l}0.149 \\
(0.201)\end{array}$ & & $\begin{array}{l}0.149 \\
(0.201)\end{array}$ & \\
\hline $\begin{array}{l}\text { Number of VC investments by industry in the } \\
\text { year before the receipt of VC }\end{array}$ & $\begin{array}{c}0.004 \\
(0.002)\end{array}$ & * & $\begin{array}{c}0.004 \\
(0.002)\end{array}$ & $*$ & $\begin{array}{c}0.004 \\
(0.002)\end{array}$ & $*$ \\
\hline Constant & $\begin{array}{l}-1.246 \\
(0.442)\end{array}$ & $* * *$ & $\begin{array}{l}-1.2465 \\
(0.442)\end{array}$ & $* * *$ & $\begin{array}{l}-1.210 \\
(0.442)\end{array}$ & $* * *$ \\
\hline \multicolumn{7}{|l|}{ Fixed effects } \\
\hline Region & Yes & & Yes & & Yes & \\
\hline Industry & Yes & & Yes & & Yes & \\
\hline N. observations & 1272 & & 1272 & & 1269 & \\
\hline
\end{tabular}

Panel D reports the first stage equation of the 2SLS model. $\ln A g e_{i, t}$ is the natural logarithm of the company's age (i.e., number of years since its foundation). $\ln A g e_{i, t}^{2}$ is the square value of $\operatorname{lnAge} e_{i, t}$. VC Year crisis $_{i}$ is a dummy variable taking value 1 if a VC-backed company receives financing from 2009 to 2013, and 0 if the year of VC financing is from 2005 until 2008. The instrumental variable for the two-stage least squares method is the number of VC investments by industry in the year before the time in which the focal company receives the financing. Standard errors are reported in parentheses.

*** denotes significance at the $1 \%$ level. ${ }^{* *}$ denotes significance at the $5 \%$ level. * denotes significance at the $10 \%$ level. 
Table 8. Employment growth in entrepreneurial ventures funded by PVCs and GOVCs before and during the crisis: Dynamic panel data models

Panel A. Regression results

\begin{tabular}{|c|c|c|c|c|c|c|}
\hline \multirow[b]{2}{*}{ lnEmployees i.t-1 $_{1}$} & \multicolumn{2}{|c|}{ Model 1} & \multicolumn{2}{|c|}{$\begin{array}{c}\text { Model } 2 \\
\text { Including } \\
\text { syndication }\end{array}$} & \multicolumn{2}{|c|}{$\begin{array}{c}\text { Model } 3 \\
\begin{array}{c}\text { Including amount } \\
\text { invested }\end{array} \\
\end{array}$} \\
\hline & $\begin{array}{l}-0.114 \\
(0.031)\end{array}$ & $* * *$ & $\begin{array}{l}-0.115 \\
(0.032)\end{array}$ & $* * *$ & $\begin{array}{l}-0.153 \\
(0.031)\end{array}$ & $* * *$ \\
\hline $\ln A g e_{i, t}$ & $\begin{array}{l}-0.105 \\
(0.017)\end{array}$ & $* * *$ & $\begin{array}{l}-0.098 \\
(0.017)\end{array}$ & $* * *$ & $\begin{array}{l}-0.064 \\
(0.017)\end{array}$ & $* * *$ \\
\hline$V C$ Year crisis $_{i, t}$ & $\begin{array}{l}-0.123 \\
(0.018)\end{array}$ & $* * *$ & $\begin{array}{l}-0.1295 \\
(0.018)\end{array}$ & $* * *$ & $\begin{array}{l}-0.130 \\
(0.017)\end{array}$ & $* * *$ \\
\hline$\left.P V C_{i, t-1} *(\text { VC Year before crisis })_{i}\right)$ & $\begin{array}{c}0.064 \\
(0.047)\end{array}$ & & $\begin{array}{c}0.052 \\
(0.058)\end{array}$ & & $\begin{array}{c}0.004 \\
(0.056)\end{array}$ & \\
\hline $\operatorname{GOVC}_{i, t-1} *\left(\right.$ VC Year before crisis $\left._{i}\right)$ & $\begin{array}{c}0.148 \\
(0.038)\end{array}$ & $* * *$ & $\begin{array}{c}0.148 \\
(0.039)\end{array}$ & $* * *$ & $\begin{array}{l}0.132 \\
(0.04)\end{array}$ & $* * *$ \\
\hline$P V C_{i, t-1} *(V C$ Year crisis $i)$ & $\begin{array}{c}0.168 \\
(0.043)\end{array}$ & $* * *$ & $\begin{array}{c}0.151 \\
(0.044)\end{array}$ & $* * *$ & $\begin{array}{c}0.092 \\
(0.044)\end{array}$ & $* *$ \\
\hline $\operatorname{GOVC}_{i, t-1} *\left(\right.$ VC Year crisis $\left._{i}\right)$ & $\begin{array}{c}0.000 \\
(0.053)\end{array}$ & & $\begin{array}{c}0.001 \\
(0.053)\end{array}$ & & $\begin{array}{l}-0.020 \\
(0.051)\end{array}$ & \\
\hline $\begin{array}{l}\text { Syndicated } \mathrm{i}_{\mathrm{t}-\mathrm{-}-1} * \\
\left(\text { VC Year before crisis }_{\mathrm{i}}\right)\end{array}$ & & & $\begin{array}{l}-0.022 \\
(0.432)\end{array}$ & & $\begin{array}{l}0.118 \\
(0.364)\end{array}$ & \\
\hline Syndicated $_{\mathrm{i}, \mathrm{t}-1} *\left(\right.$ VC Year crisis $\left.\mathrm{i}_{\mathrm{i}}\right)$ & & & $\begin{array}{c}0.470 \\
(0.194)\end{array}$ & $* *$ & $\begin{array}{c}0.312 \\
(0.174)\end{array}$ & $*$ \\
\hline $\log A m o u n t$ financed ${ }_{i, t-1}$ & & & & & $\begin{array}{c}0.021 \\
(0.002)\end{array}$ & $* * *$ \\
\hline Constant & $\begin{array}{c}0.315 \\
(0.102)\end{array}$ & $* * *$ & $\begin{array}{c}0.305 \\
(0.107)\end{array}$ & $* * *$ & $\begin{array}{c}0.395 \\
(0.113)\end{array}$ & $* * *$ \\
\hline Fixed effects & & & & & & \\
\hline $\begin{array}{l}\text { Industry } \\
\text { Region }\end{array}$ & $\begin{array}{l}\text { Yes } \\
\text { Yes }\end{array}$ & & $\begin{array}{l}\text { Yes } \\
\text { Yes }\end{array}$ & & $\begin{array}{l}\text { Yes } \\
\text { Yes }\end{array}$ & \\
\hline N. observations & 7672 & & 7672 & & 7486 & \\
\hline N. companies & 1270 & & 1270 & & 1270 & \\
\hline $\operatorname{AR}(1)$ & -6.381 & $* * *$ & -6.372 & $* * *$ & -6.349 & $* * *$ \\
\hline $\operatorname{AR}(2)$ & 0.986 & & 0.985 & & 1.176 & \\
\hline Hansen & $23.560[4]$ & & $33.966[8]$ & & $34.173[10$ & \\
\hline
\end{tabular}

The table reports the estimates of dynamic panel-data models using two-step system GMM with finite sample correction. The dependent variable is the increase in Ln(Employees) - the natural logarithm of the number of a firm's employees - relative to the previous year. The explanatory variables are: $\operatorname{lnSize}_{i, t-1}$ is the natural logarithm of the firm size -measured by the number of employees- at time $t-1 ; \ln A g e_{i, t}$ is the natural logarithm of the company's age (i.e., number of years since its foundation $P V C_{i, t-1}$ is a dummy taking the value 1 in the years following the first round completed by PVCs, lagged by one year. $G O V C_{i, t-1}$ is a dummy taking the value 1 in the years following the first round completed by a GOVCs, lagged by one year. VC Year crisis is a $_{i}$ dummy variable taking value 1 if a VC-backed firm receives financing from 2009 to 2013, and 0 if the year of VC financing is from 2005 until 2008. VC Year before crisis $s_{i}$ is defined as (1-VC Year crisis $i_{i}$ ). $\log {\text { Amount } \text { financed }_{i, t} \text { is the amount financed by the investor to the invested company. Syndicated }}_{i, t-1}$ is a dummy variable taking value 1 if GOVCs and PVCs co-invest in the specific company. The models include region and industry dummies. Robust standard errors are in round brackets. Degrees of freedom are in squared brackets.

*** denotes significance at the $1 \%$ level. ** denotes significance at the $5 \%$ level. * denotes significance at the $10 \%$ level. 
Panel B. Wald tests. Differences between PVCs and GOVCs

\begin{tabular}{|c|c|c|c|c|c|c|}
\hline & Model 1 & & Model 2 & & Model 3 & \\
\hline $\begin{array}{l}\text { Difference between PVCs and GOVCs } \\
\quad \text { (investment in the years before crisis) }\end{array}$ & $\begin{array}{l}-0.085 \\
(0.049)\end{array}$ & $*$ & $\begin{array}{l}-0.096 \\
(0.061)\end{array}$ & $*$ & $\begin{array}{l}-0.129 \\
(0.062)\end{array}$ & $* *$ \\
\hline $\begin{array}{l}\text { Difference between PVCs and GOVCs } \\
\text { (investment in the years of crisis) }\end{array}$ & $\begin{array}{c}0.167 \\
(0.066) \\
\end{array}$ & $* *$ & $\begin{array}{r}0.150 \\
(0.067) \\
\end{array}$ & $* *$ & $\begin{array}{r}0.112 \\
(0.065) \\
\end{array}$ & * \\
\hline
\end{tabular}

Panel B reports the results of the Wald test described in Section 3.3 in order to test the differences in employment growth among companies invested by PVCs and GOVCs before and during the crisis.

** denotes significance at the $5 \%$ level. * denotes significance at the $10 \%$ level.

Panel C. Wald tests. Effect of the crisis on the impact of PVCs and GOVCs

\begin{tabular}{lccccc}
\hline & Model 1 & & Model 2 & Model 3 \\
\hline Impact of PVCs: post-crisis versus before crisis & 0.104 & $* *$ & 0.099 & $*$ & 0.088 \\
& $(0.053)$ & & $(0.064)$ & $(0.065)$ \\
Effect of GOVCs: post-crisis versus before crisis & -0.148 & $* *$ & -0.147 & $* *$ & -0.152 \\
& $(0.061)$ & & $(0.061)$ & $(0.061)$
\end{tabular}

Panel C reports the results of the Wald test described in Section 3.3 in order to test changes in the impact of investments carried out by PVCs and GOVCs during the crisis versus the impact of investment done before the crisis started.

** denotes significance at the $5 \%$ level. * denotes significance at the $10 \%$ level. 